\title{
Integrated Soil Fertility Management (ISFM) on Coconut + Lanzones (Lansium domesticum Corr) Agro-ecosystem in Southern Mindanao, Philippines (1993 - 2007): with Emphasis on the Multi-Nutrient Coconut- Specific Mineral Fertilizer*. Part II. Influence on Leaf Nutrient Levels and Selected Soil Properties
}

\author{
Severino S. Magat ${ }^{1}$, Millicent I. Secretaria ${ }^{2}$, Junaldo A. Mantiquilla ${ }^{3}$ and \\ Rogaciano Z. Margate ${ }^{3}$
}

\begin{abstract}
A 15- year (1993-2007) long-term integrated soil fertility management (ISFM) study on coconut ('Laguna' tall variety) + lanzones fruit tree ('Paete' variety) agro-ecosystem was conducted using five fertilizer combinations (FCs) in a dominantly tropical wet climate growing zone (Koppen-Geiger Climate Classification, Kottek et al 2006) of Davao, Southern Mindanao, Philippines $\left(07^{\circ} 05^{\prime} \mathrm{N} 125^{\circ} 37^{\prime} \mathrm{E}\right.$. One of the objectives of the study was to determine the response of this agro-ecosystem to the combined application of inorganic multinutrient fertilizer (MNF): $\mathrm{N}+\mathrm{P}+\mathrm{K}+\mathrm{Cl}+\mathrm{S}+\mathrm{B}\left(14 \% \mathrm{~N}-5 \% \mathrm{P}_{2} \mathrm{O}_{5}-20 \% \mathrm{~K}_{2} \mathrm{O}\right.$, with $15.5 \% \mathrm{Cl}, 4.5 \% \mathrm{~S}$ and $\left.0.02 \% \mathrm{~B}\right)$ and organic fertilizer sources at different ratios by weight by tree (IF+OF at $1+0 ; 1+2 ; 2+4 ; 4+2$ and $4+4)$ on: crop productivity; soil properties, and leaf nutrient levels of the agro-ecosystem.

The influence of ISFM and MNF on yields and profitability of the agro-ecoystem coconut and lanzones fruit tree crop (Part I) had been presented earlier in the CORD J. (Magat et al 2009)

Results as presented in the first part of the work report showed that the application of the multi-nutrient inorganic fertilizer even at its lowest rate for coconut $(1 \mathrm{~kg} / \mathrm{tree} / \mathrm{yr})$ produced a significant increase in annual nut and copra yield per ha from an average of 8,890 nuts or 1.6 tons to 3 - 4 tons after 2 years of fertilizer applications. The non-significant difference in nut and copra yields of fertilizer combinations (FCs) in almost all years showed that even with the application of FC-1 (1 kg of inorganic fertilizer), the lowest rate of the multi-nutrient fertilizer, even without organic fertilizer, an annual yield over 4 tons copra per ha (or over 17, 000 nuts per ha) was produced in most of years of production, seldom achieved in coconut farms in the country.

The improvement of coconut yield and very productive lanzones fruiting stage in this cropping system may be attributed to the significant influence of fertilizer combinations on the crops' leaf nutrient contents as N, P, K, Cl and B. The long term effect of organic fertilization contributed much to the improved or enhanced soil physical conditions as the soil bulk density. Soil chemical properties as soil acidity, organic carbon (C), organic matter, available phosphorus $(\mathrm{P})$ and exchangeable potassium $(\mathrm{K})$ were generally enhanced during the 15 years of coconut and lanzones cropping under ISFM with multi-nutrient fertilizer application.

This long-term coconut + lanzones cropping agro-ecosystem proved to be a sustainable farming system. The proper integrated soil fertility management (ISFM) as a major component of the integrated crop management (ICM) using the PCA-formulated crop-specific-fertilizer multi-nutrient $14(\mathrm{~N})-5\left(\mathrm{P}_{2} \mathrm{O}_{5}\right)-20\left(\mathrm{~K}_{2} \mathrm{O}\right)-15.5(\mathrm{Cl})-4.5(\mathrm{~S})-0.02(\mathrm{~B})$ even at the lowest rate of fertilization contributed to stable soils resulting to the total productivity of the coconut + lanzones fruit tree agro-ecosystem.

Keywords: Coconut, Cocos nucifera, lanzones, Lansium domesticum, coconut+ fruit tree ecosystem, inorganic multi-nutrient fertilizer, organic fertilizer, integrated soil fertility management, leaf mineral nutrients, crop-specific fertilizer
\end{abstract}

*A part of the paper presented at the 2008 National Research Symposium, Department of Agriculture, Philippines. Best 2008 R\&D Paper (Applied Research: Technology Information/Generation-Agriculture)

\footnotetext{
${ }^{1}$ Scientist IV, Philippine Coconut Authority (PCA), Diliman, Quezon City, Philippines

${ }^{2}$ Scientist I, PCA-Davao Research Center, Bago Oshiro, Davao City, Philippines

${ }^{3}$ Former Researcher, PCA-Davao Research Center, Philippines
} 


\section{Introduction}

In 1991, PCA conceptualized the integrated soil fertility management (ISFM) and defined it------as the combined use of organic/natural and inorganic fertilizers in coconut farming aimed at achieving maximum economic yields through a sustainable, economical, environment-friendly and socially-acceptable production system (Magat, 1997). In most cases, field studies involving ISFM are long-term as the agronomic, soils and mineral nutrition aspects of farming techniques are intensively tested before conclusions and final recommendations are formulated under the mono-cropping and intercropping conditions of coconut farming. Sitespecific ISFM covers the integrated nutrient management (ICM) aspects and the complementary soil physical and biological conditions that influence the growth and productivity of crop (s) and its ecosystem. We consider that ISFM is one of the major components of the effective and efficient integrated crop management (ICM) in agriculture and farming, to be locally and globally competitive.

Intercropping in coconut farms is widely practiced in the Philippines as well as in many coconut producing countries, but sadly, only few farmers yet have attained consistent success in increasing their farm productivity. Aguilar and co-workers (1991), documenting successful coconut-based farms, concluded that three factors strongly control the success of farmer-managed farms in the Philippines, namely: 1) right agroenvironment; 2) positive attitude of the farmer; 3 ) availability of proper technologies that practical and affordable).

As intercropping aims for higher yields of coconut and intercrops to have maximum farm productivity and a profitable return to investment (labor, seeds, fertilizers and farm chemicals), proper cultural practices and fertilization or nutrient management of both coconut and intercrops should be necessary (Magat, 1990).
Fertilizer is considered worldwide as of the single, most important inputs that can immediately improve production of most agricultural crops as coconut and its suitable intercrops (i.e. corn, peanut, sweet potato, pineapple, banana, coffee, cacao and other fruit crops). At the same time, the sustainability of coconut farming system depends highly on technologies applied to conserve the soil resources or improve the soil productivity, and in this regard an integrated soil fertility management (ISFM) --------- a balance of cultural, biological and chemical or inorganic methods should be the most positive and acceptable approach and/ or farming practice consistent with integrated crop management system (ICMS) aimed at the long-term sustainability and productivity in coconut farming for the benefit of small and mediumscale farms, and less privileged and resourcelimited farmers.

\section{Objectives}

The general and specific objectives of the research work was mentioned in the earlier paper (Magat et al 2009), and this part II mainly covers the aspects on the influence of ISFM under varying ratios (parts) of inorganic and organic fertilizer combinations on leaf nutrient levels and selected soil properties.

\section{Materials and methods}

A detail presentation on these was done in the first paper (Magat et al 2009, Part I). It covered the following: 1) experimental area and planting materials; 2) experimental treatments or fertilizer combinations (FCs) and research experimental design; 3) fertilizer sources (inorganic or MNF and organic materials); 4) rates of application over the 15 years period (Table 1); and 5) sampling techniques used in the gathering of experimental data.

\section{$\underline{\text { Rates of Fertilizers: }}$}

Relevant climatological and soil data were gathered. Benchmark and periodic data 
Table 1. Actual fertilizers applied (per tree/year) under the five fertilizer combinations (FCs), on ISFM coconut + lanzones agro-ecosystem (PCA-DRC, 1993-2007)

\begin{tabular}{|c|c|c|c|c|c|c|c|c|c|c|c|c|}
\hline & & & $\mathbf{L} \quad \mathbf{A}$ & $\mathbf{N} \quad \mathbf{Z}$ & $\begin{array}{ll}\mathbf{O} & \mathbf{N} \\
\end{array}$ & $\mathbf{E}$ & CRO & Comp & ient & & & \\
\hline & & ELD & & IX & $Y_{1}$ & & & r 2 & Yr & & & \\
\hline TRMNT & PLAI & TTING & MO & NTHS & $(19$ & & & 95) & $(19$ & & & \\
\hline & \begin{tabular}{|l|}
$g$ \\
$I F$
\end{tabular} & gOF & $g I F$ & $\begin{array}{l}g \\
O F\end{array}$ & $k g I F$ & $\begin{array}{l}k g \\
O F\end{array}$ & kg IF & $\begin{array}{l}\mathrm{kg} \\
\mathrm{OF}\end{array}$ & kg IF & $\begin{array}{l}\text { kg } \\
O F\end{array}$ & $k g I F$ & $\begin{array}{l}\mathrm{kg} \\
\mathrm{OF}\end{array}$ \\
\hline FC-1 (1+0) & 63 & 0 & 125 & 0 & 0.25 & 0 & 0.38 & 0 & 0.38 & 0 & 0.32 & 0 \\
\hline FC-2 $(1+2)$ & 63 & 125 & 125 & 250 & 0.25 & 0.50 & 0.38 & 0.75 & 0.38 & 1.0 & 0.32 & 1.26 \\
\hline FC-3 $(2+4)$ & 125 & 250 & 250 & 500 & 0.50 & 1.00 & 0.75 & 1.50 & 0.75 & 2.0 & 0.64 & 2.50 \\
\hline FC-4 (4+2) & 250 & 125 & 500 & 250 & 1.00 & 0.50 & 1.50 & 0.75 & 1.50 & 1.0 & 1.26 & 1.26 \\
\hline FC-5 (4+4) & 250 & 250 & 500 & 500 & 1.00 & 1.00 & 1.50 & 1.50 & 1.50 & 2.0 & 1.26 & 2.50 \\
\hline & & & LAN & $\mathbf{O N}$ & CRO & Com & & & & & $\mathrm{COCC}$ & UT \\
\hline $\begin{array}{l}\text { TRMNT } \\
\text { (IF : OF) }\end{array}$ & $Y_{1}$ & $5^{\mathrm{c}}$ & & $6^{d}$ & & $\mathrm{r}^{\mathrm{d}}$ & & $8-9$ & Yr 1 & & $\overline{Y r}$ & $0-15^{\mathrm{e}}$ \\
\hline & $(19$ & 98) & & 999) & & 000) & $(200$ & 2002) & $(2003$ & (007) & $(199$ & 2007) \\
\hline & $\begin{array}{l}\mathrm{kg} \\
\mathrm{IF}\end{array}$ & \begin{tabular}{|l|}
$k g$ \\
$O F$ \\
\end{tabular} & $\begin{array}{c}\mathrm{kg} \\
I F\end{array}$ & $\begin{array}{l}g \\
O F \\
\end{array}$ & $k g I F$ & $\begin{array}{l}g \\
O F \\
\end{array}$ & kg IF & $\begin{array}{l}\mathrm{kg} \\
\mathrm{OF} \\
\end{array}$ & kg IF & $\begin{array}{l}\mathrm{kg} \\
\mathrm{OF}\end{array}$ & $k g I F$ & $\begin{array}{l}\mathrm{kg} \\
O F \\
\end{array}$ \\
\hline FC-1 $(1+0)$ & 0.43 & 0 & $\begin{array}{l}80 \mathrm{~g} \\
\mathrm{KCl}+\end{array}$ & \begin{tabular}{|l|}
0 \\
$(25$
\end{tabular} & $\begin{array}{l}(80 \mathrm{~g} \\
\mathrm{KCl}+\end{array}$ & 0 & 0.38 & $\begin{array}{l}0 \\
(25 \mathrm{pc}\end{array}$ & 0.38 & 0 & 1 & 0 \\
\hline FC-2 (1+2) & 0.43 & 0.75 & $400 \mathrm{~g}$ & pcs & $400 \mathrm{~g}$ & 0 & 0.38 & coco & 0.38 & 0 & 1 & 2 \\
\hline FC-3 $(2+4)$ & 0.62 & 1.50 & $\mathrm{RP})$ & coco husk & \&/ $\mathrm{RP}$ & 0 & 0.75 & husk & 0.75 & 0 & 2 & 4 \\
\hline FC-4 (4+2) & 0.99 & 0.75 & ditto & tree) & Ditto & 0 & 1.50 & ditto & 1.50 & 0 & 4 & 2 \\
\hline FC-5 (4+4) & 0.99 & 1.50 & ditto & ditto & Ditto & 0 & 1.50 & ditto & 1.50 & 0 & 4 & 4 \\
\hline
\end{tabular}

a Additional treatment in October 1996: applying $50 \mathrm{~g}$ of zinc sulfate per tree on one sub-plot with splitplot design

${ }^{\mathrm{b}}$ Inorganic fertilizer application reduced per latest nutritional diagnosis

${ }^{c}$ Half of rate for the year was applied, and subsequently with $40 \mathrm{~g} \mathrm{KCl}+200 \mathrm{~g}$ rock phosphate (RP) per tree in blanket application

d Blanket application of $80 \mathrm{~g} \mathrm{KCl}+400 \mathrm{~g} \mathrm{RP}$, split in two application: Jun \& Oct, while the commercial organic fertilizer (Biogro) was replaced by 25 coconut husk(full) divided to 4-6 into pieces before topsoil placement, per lanzones tree. Biogro commercial organic fertilizer has the NPK fertilizer grade of (1.2.5 - 4.5 - 1.75) with $5-25 \% \mathrm{CaO}$ and $1-5 \% \mathrm{MgO}$ and some micronutrients (produced by BIOrganix Technology, Inc)

e Starting 2004, the physical blended 14-5-20 (with $0.02 \% \mathrm{~B}, 15 \% \mathrm{Cl}$ and $4.5 \% \mathrm{~S}$ ) inorganic fertilizer (IF) was replaced with the commercial granulated 14-5-20 (commercial ATLAS brand CocoGro)

on some important soil chemical, physical an biological properties were determined following the Research Guide on the conduct of Agronomic and Nutrition Studies in Coconut (Margate and Magat, 1991). 
Leaf sampling (leaf rank \#14) of bearing coconut trees were done prior to application of treatments and ensuing years, following standard procedures (Magat 1976 and Magat 2007). Also, the leaf sampling of lanzones intercrop at different development stages and final cropping year were done, following the methods presented by Magat (2005). The benchmark and succeeding periodic (annual) soil and leaf samples properly dried and identified before these were submitted to the Plant Tissue Analysis Laboratory, Plant and Soil Analysis Division, Philippine Coconut Authority, Central Office, Diliman, Quezon City. Soil samples under the subject agro-ecosystem were analyzed for selected soil properties, and the coconut and lanzones fruit tree samples were analyzed for macronutrients (N, P, K, Ca, $\mathrm{Mg}, \mathrm{Na}, \mathrm{Cl}$ and $\mathrm{S}$ ) and micronutrients $(\mathrm{B}, \mathrm{Zn}, \mathrm{Fe} \mathrm{Mn}$ and $\mathrm{Cu}$ ), following standard procedures and methods (Raquepo and Pabustan, 2003).

Data were evaluated using statistical analyzes, aided by available computer softwares.

\section{Results and discussion}

\section{Effects of ISFM on Leaf Nutrient Levels of Coconut}

The improvement in the leaf nutritional status of experimental palms could be the main reason for the significant increase in nut and copra yield per ha of the coconut immediately after one year of fertilizer application (Tables 2.A and 2.B). On the second and third year of fertilization (1995-96), a significant effect of the fertilizer treatments was observed on leaf chloride $(\mathrm{Cl})$ with palms under higher rates of fertilizer (FC-4 and FC-5) having significantly higher $\mathrm{Cl}$ than those applied with lower rates. Other leaf nutrients were not significantly affected by different fertilizer combinations (Table2.C).

In the following year (1998), the effect of fertilizer combinations was noted on the leaf levels of $\mathrm{Cl}, \mathrm{Ca}$, and B (Table 2.G). The higher rates of fertilizer combinations had significantly higher $\mathrm{Cl}$ and $\mathrm{S}$ tended to lower leaf boron (B) level. Fertilizer combination FC-4 had affected by the leaf $\mathrm{Cl}$ contents, likely due to relatively high rates of fertilizer application. Studies showed that $\mathrm{Cl}$ enhances the uptake of cations like K, Ca and Mg (Magat and Goh, 1988). In general, the nutrition of the palms was highly satisfactory in all treatments (FC-1 to FC-5), the main reason for the non-significant differences in yield among treatments. While the lower fertilizer combinations had higher B level indicating that the lowest annual rate of application of the MNF 14-5-20-15.5Cl-4.5S$0.02 \mathrm{~B}$ fertilizer (at $1 \mathrm{~kg} /$ tree/year) was already adequate for the high performance of the coconut palms.

In the succeeding years, leaf analysis of coconut indicated that higher levels of inorganic MNF and organic fertilizer generally and significantly lowered leaf $\mathrm{K}$ level (cropping 2002, Table 2.H). This was clearly seen in palms with FC-3 and FC-5. The commonly observed $\mathrm{Ca}-\mathrm{K}$ and $\mathrm{Mg}-\mathrm{K}$ antagonisms were seemingly manifested in the palm leaves. Other micro-nutrients that tended to decreased in leaf levels at higher fertilizer rates included $\mathrm{B}, \mathrm{Cu}$, $\mathrm{Fe}$, although not at significantly. However, these changes in nutrient concentrations did not affect the yield of palms, significantly.

Referenced to the normal or adequacy of leaf nutrients levels of lanzones fruit tree proposed for the fruit tree nutritional diagnosis based on leaves (Magat and Mantiquilla, 2005), and the leaf nutrient status of the trees applied with FC-1, indicating sufficiency in levels of nutrients in this study even at the lowest rate of IF, the nutritional status of the crop in macro and micronutrients could be assessed. It was noted that some leaf nutrients are likely at satisfactory levels such as: leaf N, P, Na, S, B, while the rest $(\mathrm{K}, \mathrm{Mg}, \mathrm{Zn}, \mathrm{Mn}, \mathrm{Cu}$ and $\mathrm{Fe})$ are likely below adequacy levels. However, due to the consistent high yields of

Table 2. Leaf analysis results of Laguna tall 'LAGT' coconut (at leaf rank no. 14), PCA-DRC

\begin{tabular}{|c|c|c|c|c|c|c|c|c|c|}
\hline A. Year 1993 & \multicolumn{9}{|c|}{$\%$ dry matter } \\
\hline Replicate & $\mathbf{N}$ & $\mathbf{P}$ & $\mathbf{K}$ & $\mathrm{Ca}$ & Mg & $\mathrm{Na}$ & Cl & $\mathbf{S}$ & B (ppm) \\
\hline I & 1.960 & 0.136 & 1.247 & 0.382 & 0.269 & 0.063 & 0.382 & 0.204 & 10.0 \\
\hline II & 1.803 & 0.137 & 1.299 & 0.416 & 0.300 & 0.055 & 0.375 & 0.202 & 10.6 \\
\hline
\end{tabular}




\begin{tabular}{|c|c|c|c|c|c|c|c|c|c|}
\hline III & 1.907 & 0.128 & 1.142 & 0.339 & 0.277 & 0.077 & 0.331 & 0.176 & 9.0 \\
\hline TOTAL & 5.670 & 0.401 & 3.688 & 1.137 & 0.846 & 0.195 & 1.088 & 0.582 & 29.6 \\
\hline MEAN & 1.890 & 0.134 & 1.229 & 0.379 & 0.282 & 0.065 & 0.363 & 0.194 & 9.9 \\
\hline $\begin{array}{l}\text { B. Year } 1994 \\
\text { TRMT }\end{array}$ & \multicolumn{9}{|c|}{$\%$ dry matter } \\
\hline FC-1 (1+0) & 2.110 & 0.143 & 1.345 & 0.359 & 0.235 & 0.067 & 0.528 & 0.188 & 10.1 \\
\hline FC-2 $(1+2)$ & 2.087 & 0.152 & 1.419 & 0.377 & 0.232 & 0.071 & 0.547 & 0.188 & 10.7 \\
\hline FC-3 $(2+4)$ & 2.155 & 0.138 & 1.362 & 0.357 & 0.230 & 0.068 & 0.682 & 0.186 & 9.2 \\
\hline FC-4 (4+2) & 2.196 & 0.145 & 1.285 & 0.423 & 0.249 & 0.065 & 0.736 & 0.188 & 11.3 \\
\hline FC-5 (4+4) & 2.115 & 0.139 & 1.333 & 0.350 & 0.217 & 0.066 & 0.677 & 0.187 & 9.8 \\
\hline MEAN & 2.133 & 0.144 & 1.349 & 0.373 & 0.233 & 0.067 & 0.634 & 0.187 & 10.2 \\
\hline $\begin{array}{l}\text { Stat.sig. } \\
\text { c.v. }(\%)\end{array}$ & $\begin{array}{c}\mathrm{ns} \\
2.10\end{array}$ & $\begin{array}{c}\mathrm{ns} \\
4.00\end{array}$ & $\begin{array}{c}\mathrm{ns} \\
4.50\end{array}$ & $\begin{array}{c}\mathrm{ns} \\
11.50\end{array}$ & $\begin{array}{c}\mathrm{ns} \\
6.80\end{array}$ & $\begin{array}{c}\mathrm{ns} \\
49.40\end{array}$ & $\begin{array}{c}\mathrm{ns} \\
12.10\end{array}$ & $\begin{array}{c}\mathrm{ns} \\
5.00\end{array}$ & $\begin{array}{c}\mathrm{ns} \\
10.4\end{array}$ \\
\hline $\begin{array}{l}\text { C. Year } 1995 \\
\text { TRMT }\end{array}$ & \multicolumn{9}{|c|}{$\%$ dry matter } \\
\hline FC-1 (1+0) & 2.004 & 0.141 & 1.333 & 0.337 & 0.234 & 0.066 & $0.676 \mathrm{~b}$ & 0.185 & 8.133 \\
\hline FC-2 $(1+2)$ & 2.004 & 0.157 & 1.225 & 0.357 & 0.228 & 0.070 & $0.650 \mathrm{~b}$ & 0.178 & 7.967 \\
\hline FC-3 $(2+4)$ & 1.991 & 0.137 & 1.322 & 0.373 & 0.232 & 0.067 & $0.788 \mathrm{ab}$ & 0.175 & 7.433 \\
\hline FC-4 (4+2) & 2.061 & 0.141 & 1.252 & 0.409 & 0.232 & 0.065 & $0.900 \mathrm{a}$ & 0.182 & 7.567 \\
\hline FC-5 (4+4) & 2.071 & 0.139 & 1.293 & 0.368 & 0.256 & 0.067 & $0.825 \mathrm{a}$ & 0.182 & 7.300 \\
\hline MEAN & 2.026 & 0.143 & 1.285 & 0.369 & 0.236 & 0.067 & 0.768 & 0.181 & 7.680 \\
\hline $\begin{array}{l}\text { Stat.sig. } \\
\text { c.v. }(\%)\end{array}$ & $\begin{array}{c}\mathrm{ns} \\
2.80 \\
\end{array}$ & $\begin{array}{c}\mathrm{ns} \\
6.50 \\
\end{array}$ & $\begin{array}{c}\mathrm{ns} \\
5.80\end{array}$ & $\begin{array}{c}\mathrm{ns} \\
8.60 \\
\end{array}$ & $\begin{array}{c}\mathrm{ns} \\
6.70 \\
\end{array}$ & $\begin{array}{c}\mathrm{ns} \\
43.40 \\
\end{array}$ & $\begin{array}{c}\mathrm{ns} \\
6.70 \\
\end{array}$ & $\begin{array}{c}\mathrm{ns} \\
4.00 \\
\end{array}$ & $\begin{array}{c}\mathrm{ns} \\
5.10\end{array}$ \\
\hline $\begin{array}{l}\text { D. Year } 1996 \\
\text { TRMT }\end{array}$ & \multicolumn{9}{|c|}{$\%$ dry matter } \\
\hline & \multicolumn{9}{|c|}{$\%$ dry matter } \\
\hline FC-1 $(1+0)$ & 2.019 & 0.141 & 1.312 & $0.311 \mathrm{~b}$ & 0.212 & 0.063 & $0.654 \mathrm{c}$ & 0.163 & 8.900 \\
\hline FC- $2(1+2)$ & 1.988 & 0.142 & 1.349 & $0.347 \mathrm{~b}$ & 0.207 & 0.058 & $0.688 \mathrm{c}$ & 0.157 & 9.367 \\
\hline FC-3 $(2+4)$ & 1.960 & 0.132 & 1.374 & $1.353 \mathrm{ab}$ & 0.216 & 0.072 & $0.855 \mathrm{ab}$ & 0.150 & 8.800 \\
\hline FC-4 (4+2) & 1.921 & 0.133 & 1.251 & $1.429 \mathrm{a}$ & 0.223 & 0.070 & $0.908 \mathrm{a}$ & 0.154 & $\begin{array}{l}0.000 \\
9.100\end{array}$ \\
\hline FC-5 (4+4) & 2.076 & 0.137 & 1.192 & $1.383 \mathrm{ab}$ & 0.208 & 0.067 & $0.770 \mathrm{bc}$ & 0.154 & 8.300 \\
\hline $\begin{array}{l}\text { ]Stat.sig. } \\
\text { c.v. (\%) }\end{array}$ & $\begin{array}{c}\mathrm{ns} \\
4.10 \\
\end{array}$ & $\begin{array}{c}\mathrm{ns} \\
2.90\end{array}$ & $\begin{array}{c}\mathrm{ns} \\
6.80\end{array}$ & $\begin{array}{c}* \\
10.20\end{array}$ & $\begin{array}{c}\mathrm{ns} \\
4.80\end{array}$ & $\begin{array}{c}\mathrm{ns} \\
38.70\end{array}$ & $\begin{array}{l}* * \\
6.20\end{array}$ & $\begin{array}{c}\mathrm{ns} \\
4.70\end{array}$ & $\begin{array}{c}\mathrm{ns} \\
4.10\end{array}$ \\
\hline $\begin{array}{l}\text { E. Year } 1997 \\
\text { TREATMENT }\end{array}$ & $\mathbf{N}$ & $\mathbf{P}$ & $\mathbf{K}$ & $\mathbf{C a}$ & $\begin{array}{c}\text { dry mat } \\
\mathbf{M g}\end{array}$ & $\mathbf{N a}$ & Cl & $\mathbf{S}$ & B (ppm) \\
\hline FC-1 (1+0) & 1.832 & 0.143 & 1.313 & 0.334 & 0.211 & 0.076 & 0.697 & - & 8.933 \\
\hline FC-2 $(1+2)$ & 1.838 & 0.147 & 1.317 & 0.355 & 0.206 & 0.092 & 0.776 & - & 9.033 \\
\hline FC-3 $(2+4)$ & 1.806 & 0.133 & 1.329 & 0.349 & 0.228 & 0.085 & 0.760 & - & 8.967 \\
\hline FC-4 $(4+2)$ & 1.869 & 0.135 & 1.174 & 0.439 & 0.229 & 0.073 & 0.911 & - & 8.500 \\
\hline FC-5 (4+4) & 1.887 & 0.137 & 1.299 & 0.386 & 0.228 & 0.074 & 0.861 & - & 8.367 \\
\hline MEAN & 1.846 & 0.139 & 1.286 & 0.373 & 0.220 & 0.080 & 0.801 & - & 8.760 \\
\hline $\begin{array}{l}\text { Stat.sig. } \\
\text { c.v. }(\%)\end{array}$ & $\begin{array}{c}\mathrm{ns} \\
2.00\end{array}$ & $\begin{array}{c}\mathrm{ns} \\
4.40\end{array}$ & $\begin{array}{c}\mathrm{ns} \\
4.60\end{array}$ & $\begin{array}{c}\mathrm{ns} \\
10.30\end{array}$ & $\begin{array}{c}\mathrm{ns} \\
6.30\end{array}$ & $\begin{array}{c}\mathrm{ns} \\
42.30\end{array}$ & $\begin{array}{c}\mathrm{ns} \\
10.30\end{array}$ & $\begin{array}{l} \\
-\end{array}$ & $\begin{array}{c}\mathrm{ns} \\
6.00\end{array}$ \\
\hline $\begin{array}{l}\text { G. Year } 1998 \\
\text { TREATMENT }\end{array}$ & $\mathbf{N}$ & $\mathbf{P}$ & K & Ca & $\begin{array}{l}\text { dry mat } \\
\text { Mg }\end{array}$ & $\mathbf{N a}$ & Cl & $\mathbf{S}$ & B (ppm) \\
\hline FC-1 (1+0) & 1.750 & 0.141 & 1.182 & $0.358 \mathrm{~b}$ & 0.266 & 0.053 & $0.788 \mathrm{c}$ & - & $8.00 \mathrm{a}$ \\
\hline FC-2 $(1+2)$ & 1.685 & 0.144 & 1.248 & $0.393 \mathrm{ab}$ & 0.26 & 0.057 & $0.825 b c$ & - & $8.17 \mathrm{a}$ \\
\hline FC-3 $(2+4)$ & 1.762 & 0.137 & 1.143 & $0.408 \mathrm{ab}$ & 0.267 & 0.059 & $0.886 \mathrm{bc}$ & - & $7.40 \mathrm{ab}$ \\
\hline FC-4 (4+2) & 1.742 & 0.136 & 1.191 & $0.440 \mathrm{a}$ & 0.265 & 0.06 & $1.019 \mathrm{a}$ & - & $7.60 \mathrm{ab}$ \\
\hline FC-5 (4+4) & 1.721 & 0.136 & 1.171 & $0.409 \mathrm{ab}$ & 0.265 & 0.072 & $0.936 \mathrm{ab}$ & - & 6.93 \\
\hline MEAN & 1.732 & 0.139 & 1.187 & 0.402 & 0.265 & 0.06 & 0.891 & - & 7.62 \\
\hline $\begin{array}{l}\text { Stat.sig. } \\
\text { c.v. }(\%)\end{array}$ & $\begin{array}{l}\mathrm{ns} \\
2.0\end{array}$ & $\begin{array}{l}\text { ns } \\
3.3\end{array}$ & $\begin{array}{l}\mathrm{ns} \\
7.4\end{array}$ & $\begin{array}{c}* .7 \\
5.7\end{array}$ & $\begin{array}{l}\mathrm{ns} \\
5.8\end{array}$ & $\begin{array}{c}\mathrm{ns} \\
48.5\end{array}$ & $\begin{array}{l}* .01 \\
5.1\end{array}$ & - & $\begin{array}{l}3.02 \\
3.7\end{array}$ \\
\hline
\end{tabular}


Table 2. Continuation..........

\begin{tabular}{|c|c|c|c|c|c|c|c|c|c|c|c|c|c|}
\hline \multirow{2}{*}{$\begin{array}{l}\text { H. Year } 2002 \\
\text { TRMT. }\end{array}$} & \multicolumn{8}{|c|}{$\%$ dry matter } & \multicolumn{5}{|c|}{ in ppm } \\
\hline & $\mathbf{N}$ & $\mathbf{P}$ & $\mathbf{K}$ & $\mathbf{C a}$ & Mg & $\mathbf{N a}$ & Cl & $\mathbf{S}$ & B & $\mathbf{Z n}$ & Mn & $\mathrm{Cu}$ & $\mathrm{Fe}$ \\
\hline FC-1 (1+0) & 1.980 & 0.150 & $1.44 \mathrm{a}$ & 0.350 & $0.24 \mathrm{ab}$ & 0.060 & 0.73 & 0.170 & 10.33 & $26.90 \mathrm{ab}$ & 151.90 & 3.97 & 71.27 \\
\hline FC-2 $(1+2)$ & 2.010 & 0.140 & $1.34 \mathrm{ab}$ & 0.380 & $0.22 \mathrm{~b}$ & 0.060 & 0.73 & 0.180 & 9.97 & $28.77 \mathrm{ab}$ & 155.83 & 3.57 & 69.4 \\
\hline FC-3 $(2+4)$ & 2.030 & 0.140 & $1.20 \mathrm{~b}$ & 0.420 & $0.24 \mathrm{~b}$ & 0.070 & 0.77 & 0.180 & 9.93 & $25.03 \mathrm{ab}$ & 197.57 & 3.70 & 78.5 \\
\hline FC-4 $(4+2)$ & 2.080 & 0.140 & $1.23 \mathrm{ab}$ & 0.430 & $0.26 \mathrm{ab}$ & 0.060 & 0.85 & 0.170 & 10.27 & $32.03 \mathrm{a}$ & 200.63 & 3.77 & 78.57 \\
\hline FC-5 (4+4) & 2.120 & 0.140 & $1.20 \mathrm{~b}$ & 0.420 & $0.27 \mathrm{a}$ & 0.060 & 0.84 & 0.170 & 9.17 & $22.53 \mathrm{~b}$ & 184.67 & 3.50 & 67.03 \\
\hline MEAN & 2.044 & 0.142 & 1.280 & 0.400 & 0.250 & 0.062 & 0.784 & 0.174 & 9.934 & 27.050 & 178.120 & 3.702 & 72.95 \\
\hline Stat. sig. & ns & ns & $*$ & ns & $*$ & ns & ns & ns & ns & $*$ & ns & ns & ns \\
\hline c.v. $(\%)$ & 5.50 & 2.20 & 6.40 & 6.80 & 6.00 & 40.90 & 7.10 & 5.50 & 6.70 & 11.00 & 13.70 & 14.70 & 10.9 \\
\hline I. Year 2007 & \multicolumn{8}{|c|}{$\%$ dry matter } & \multicolumn{5}{|c|}{ in ppm } \\
\hline TRMT. & $\mathrm{N}$ & $\mathrm{P}$ & $\mathrm{K}$ & $\mathrm{Ca}$ & $\mathrm{Mg}$ & $\mathrm{Na}$ & $\mathrm{Cl}$ & S & B & $\mathrm{Zn}$ & $\mathrm{Mn}$ & $\mathrm{Cu}$ & $\mathrm{Fe}$ \\
\hline FC-1 $(1+0)$ & 1.908 & 0.143 & 1.38 & 0.35 & 0.193 & 0.329 & 0.646 & 0.170 & 12.67 & 26.2 & 194.3 & 4.8 & 143.3 \\
\hline FC-2 $(1+2)$ & 1.883 & 0.152 & 1.365 & 0.369 & 0.183 & 0.361 & 0.586 & 0.166 & 12.67 & 29.5 & 177.2 & 4.7 & 136.1 \\
\hline FC-3 (2+4) & 1.897 & 0.146 & 1.285 & 0.397 & 0.193 & 0.339 & 0.714 & 0.175 & 12.07 & 27.2 & 222.8 & 4.7 & 151.7 \\
\hline Stat. Sig. & ns & ns & ns & ns & ns & ns & ns & ns & ns & ns & ns & ns & $\mathrm{ns}$ \\
\hline c.v. $(\%)$ & 3.1 & 4.6 & 19.1 & 8.6 & 4.8 & 16.2 & 21.6 & 4.8 & 7.2 & 8.6 & 12.7 & 3.2 & 19.2 \\
\hline
\end{tabular}

the coconut crop, these subnormal concentration of nutrients could be likely a result of the physiological "dilution effect" observed in leaf nutrient content (concentration) when palms develops rapidly with very high biomass, as well as under high yields (annual yield of 150 nuts or higher, $3.5 \mathrm{t}$ copra or higher).

During the year, an insect pest, the bark borer attacked the lanzones stems and branches. Integrated pest control measures were done i.e. scraping the lanzones bark to remove the larva of the insect pest and spraying of insecticide $(D E C I S)$ on the affected areas. These control measures significantly minimized the damage on trees. The pest had been observed every now and then, but did not cause significant effect on the yield of lanzones trees.

Effects of ISFM on leaf nutrient levels of young lanzones fruit trees

On the nutritional status of lanzones, except for leaf B (at higher OF fertilizer rates), the fertilizer combinations (FCs) did not affect the vegetative growth of lanzones on its early stage-1996 (Table 3A). However, in the succeeding year (1997), the fertilizer combinations (FCs) tended to increase the leaf $\mathrm{N}$, $\mathrm{Cl}$ and $\mathrm{Mn}$ with increasing rates of IF and OF. However, for the leaf $\mathrm{K}$, the trend was the opposite in relation to increasing rates of IF and OF (Table 3B). Only leaf Ca was significantly increased with $\mathrm{Zn}$ application (50 g/tree) but leaf $\mathrm{P}$ and $\mathrm{K}$ significantly decreased and did not influence the leaf contents of micronutrients $\mathrm{B}$, $\mathrm{Zn}$ and $\mathrm{Mn}$. The leaf nutrient levels at FC-5 was significantly higher over FC-1 in terms of leaf $\mathrm{N}, \mathrm{Cl}$ and $\mathrm{Mn}$; while that of leaf $\mathrm{K}$ content was significantly higher in FC-1 over FC-5 application.

Three years after initial fertilization (1996), the leaf results analysis of the lanzones crop showed no significant effects of the fertilizer treatments on all leaf nutrients except for the leaf boron (B) (Table 3.A). The highest rate of fertilizer application, i.e., IF+OF (FC-5) apparently increased the leaf $\mathrm{B}$ in lanzones. It

should be understood that lanzones was still at its vegetative stage; hence, high leaf B may have only slightly influenced fruit tree growth.

In 1997 (4 years from field-planting of lanzones crop), significant levels of leaf nutrients: N, P.K, $\mathrm{Cl}$ and $\mathrm{Mn}$ as affected by fertilizer treatments were noted (Table 3.B). The FC-5 application was significantly higher over FC-1 in terms of $\mathrm{N}, \mathrm{Cl} \mathrm{Mn}$, while leaf $\mathrm{K}$ content was significantly higher in trees with FC-1 applications over FC- 5. Four years later, only leaf $\mathrm{P}$ and $\mathrm{S}$ were significantly affected by fertilizer treatments (Table 3.C). Higher levels of $\mathrm{P}$ were observed in FC-2 as well as FC-3 and FC-5. These results indicated that the effect of higher rates of application was just comparable with the lower ones (FC-2 vs FC-5). Likely, the build-up of leaf $\mathrm{P}$ by ISFM had induced flowering, improved the growth and yield of lanzones as in the case of FC-2 application.

Effects of ISFM on leaf nutrient levels of fruiting lanzones 
As to the leaf nutrients of lanzones at this critical fruiting stage, only leaf $\mathrm{P}$ and $\mathrm{S}$ were significantly affected by the fertilizer treatments (Table 3.C). Higher level $\mathrm{P}$ was observed in FC-2 $(11 \mathrm{~F}+2 \mathrm{FO})$ as well as FC- $3(2 \mathrm{IF}+4 \mathrm{FO})$ and FC-5 (4 IF + 4 OF).

Leaf Sulfur (S), on the other hand, was significantly increased in FC-3, FC-4 and FC - 5 applications, but, this did not influence the initial flowering of lanzones. Clearly, the high leaf S was attributed to the higher rates of supplied sulfur from gypsum $\left(\mathrm{CaSO}_{4} \cdot 2 \mathrm{H}_{2} \mathrm{O}\right)$ of the physically blended MNF. With gypsum containing $18 \% \mathrm{~S}$ and $23 \% \mathrm{Ca}$, an application of $1 \mathrm{~kg} / \mathrm{tree}$ of the MNF [14-5-20-15.5(Cl)-4.5(S)0.02 (B)] supplied $1.26 \mathrm{~g} \mathrm{~S}$ and $1.61 \mathrm{~g} \mathrm{Ca} /$ tree.

For 2004, leaf analysis of lanzones crop was only done on selected fertilizer treatments ((FC-1, FC-2 and FC-3). From the data obtained for lanzones trees with and without $\mathrm{Zn}$ plots (Table 3.D, it was observed that in plots (fruit trees) with $+\mathrm{Zn}$ application, only leaf $\mathrm{B}$ was significantly affected by these three treatments, with FC-2 having significantly higher leaf B level. On the other hand, plots with $+\mathrm{Zn}$ application, significantly affected leaf $\mathrm{N}$. Appreciably, at this stage of the development of the lanzones trees $\left(11^{\text {th }}\right.$ year $)$, the fruit crop likely had reached adequate levels of most of the nutrients $(\mathrm{N}, \mathrm{P}, \mathrm{Ca}, \mathrm{Cl}, \mathrm{S}, \mathrm{Mn}, \mathrm{Cu}$ and $\mathrm{Fe}$ ) needed for fruiting. While, lower levels of some leaf nutrient contents in $\mathrm{K}, \mathrm{Mg}, \mathrm{B}, \mathrm{Zn}$ were noted in the $11^{\text {th }}$ year. This may be attributed to the transport or movement of these nutrients to the developing fruits, resulting in the decreased concentration levels in leaves, On the $12^{\text {th }}$ year, only leaf $\mathrm{Ca}$ and $\mathrm{Zn}$ level were significantly affected by fertilizer treatments. By comparing with the leaf nutrient normal/adequacy levels of lanzones (Magat, 2005) indicated in Table 3.D, the leaf nutrient status of the lanzones trees applied with FC-1 (with multi-nutrient inorganic fertilizer only), the nutritional adequacy status of the crop in macro- and micro-nutrients could be determined. Obviously, it was noted that most leaf nutrients were likely at satisfactory levels such as: leaf $\mathrm{P}, \mathrm{K}, \mathrm{Na}, \mathrm{S}, \mathrm{B}, \mathrm{Zn}$ and $\mathrm{Cu}$; but the rest $(\mathrm{N}, \mathrm{Ca}, \mathrm{Mg}, \mathrm{Mn}$ and $\mathrm{Fe}$ ) may be considered as still at likely below normal levels or this could be a "dilution effect" influence on nutrients in plants.

A guide for normal and adequate leaf nutrient levels for bearing lanzones fruit crop was earlier presented by Magat (2005) for macronutrients (\%): N, 2.72; P, 0.20; K, 2.03; $\mathrm{Ca}, 1.37 ; \mathrm{Mg}, 0.38 ; \mathrm{Na}, 0.03 ; \mathrm{Cl}, 0.25 ; \mathrm{S}, 0.19$; and for the micronutrients (ppm): B, 54; Zn, 32; $\mathrm{Mn}, 68 ; \mathrm{Fe}, 162 ; \mathrm{Cu}, 21$. In final cropping year of 2007, leaf sampled after the final harvest (2007), except for leaf $\mathrm{P}, \mathrm{K} \mathrm{Mg}, \mathrm{Cl}, \mathrm{S}$ and $\mathrm{Na}$, the other leaf nutrients (N, Ca, B, Zn, Mn, Fe and $\mathrm{Cu}$ ) were apparently lower than normal levels (Table 3.G). This decreased in leaf nutrient levels indicates that the heavy fruiting during the year had required higher quantities of nutrients by the fruit tree Thus, there is a need to provide fertilizers to enhance vegetative growth for the next cropping year.

\section{Effects of ISFM: fertilizer combinations on soil properties}

\section{Physical Properties}

The effect of fertilizer treatments on the soil physical characteristic was evaluated in terms of its soil bulk density (SBD). The SBD, mass of the dry soil per unit bulk volume (usually expressed as $\mathrm{g} / \mathrm{cc}$ )) was affected by fertilizer treatments over time (15 long years).

The SBD of soil taken from the rhizospheres of coconut and lanzones showed no significant difference at the second $\left(2^{\text {nd }}\right)$ year of fertilization (Table 4). The result suggests that two years of organic fertilizer (OF) application on coconut + lanzones cropping system did not affect yet the soil BD (inversely related to soil pososity and soil 
Table 3. Leaf analysis of lanzones trees ( $3^{\text {rd }}$ from top of tertiary branch), PCA-DRC, 1996-1997

\begin{tabular}{|c|c|c|c|c|c|c|c|c|c|c|c|}
\hline \multirow{2}{*}{ TREATMENT } & \multicolumn{8}{|c|}{$(\% \mathrm{DM})$} & \multicolumn{3}{|c|}{ (ppm) } \\
\hline & $\mathbf{N}$ & $\mathbf{P}$ & K & Ca & Mg & $\mathrm{Na}$ & Cl & $\mathbf{S}$ & B & $\mathbf{Z n}$ & Mn \\
\hline FC-1 (1+0) & 2.356 & 0.150 & 2.021 & 0.923 & 0.310 & 0.042 & 0.854 & 0.187 & $48.83 b$ & - & - \\
\hline FC-2 $(1+2)$ & 2.290 & 0.154 & 2.137 & 1.028 & 0.326 & 0.053 & 0.870 & 0.209 & $53.53 \mathrm{~b}$ & - & - \\
\hline FC-3 (2+4) & 2.357 & 0.156 & 2.125 & 1.146 & 0.344 & 0.058 & 1.301 & 0.202 & $54.90 \mathrm{ab}$ & - & - \\
\hline FC-4 (4+2) & 2.410 & 0.145 & 1.913 & 1.085 & 0.320 & 0.057 & 1.073 & 0.205 & $51.80 \mathrm{~b}$ & - & - \\
\hline FC-5 (4+4) & 2.202 & 0.148 & 2.491 & 1.023 & 0.302 & 0.046 & 0.913 & 0.200 & $62.33 \mathrm{a}$ & - & - \\
\hline Mean & 2.323 & 0.151 & 2.137 & 1.041 & 0.321 & 0.051 & 1.002 & 0.200 & 54.28 & - & - \\
\hline Stat. sign. & $\mathrm{ns}$ & ns & ns & ns & ns & ns & ns & ns & $* *$ & - & - \\
\hline C.V. $(\%)$ & 6.30 & 6.90 & 12.00 & 17.80 & 6.50 & 40.70 & 47.90 & 4.10 & 5.60 & - & - \\
\hline
\end{tabular}

\begin{tabular}{|c|c|c|c|c|c|c|c|c|c|c|c|}
\hline \multirow{2}{*}{ TREATMENT } & \multicolumn{8}{|c|}{ (\% DM) } & \multicolumn{3}{|c|}{ (ppm) } \\
\hline & $\mathbf{N}$ & $\mathbf{P}$ & $\mathbf{K}$ & $\mathrm{Ca}$ & $\mathrm{Mg}$ & $\mathbf{N a}$ & Cl & $\mathbf{S}$ & B & $\mathbf{Z n}$ & Mn \\
\hline FC-1 (1+0) & $1.720 \mathrm{c}$ & $0.140 \mathrm{~b}$ & $2.972 \mathrm{a}$ & 0.656 & 0.343 & 0.051 & $0.504 \mathrm{~b}$ & - & 57.333 & 41.300 & $81.133 \mathrm{c}$ \\
\hline FC-2 $(1+2)$ & $1.892 \mathrm{bc}$ & $0.172 \mathrm{a}$ & $2.623 \mathrm{ab}$ & 0.835 & 0.328 & 0.067 & $0.546 \mathrm{~b}$ & - & 57.300 & 56.967 & $114.033 \mathrm{c}$ \\
\hline FC-3 $(2+4)$ & $2.055 \mathrm{ab}$ & $0.149 \mathrm{~b}$ & $2.371 \mathrm{ab}$ & 0.766 & 0.321 & 0.051 & $0.679 \mathrm{ab}$ & - & 54.200 & 43.267 & $197.700 \mathrm{bc}$ \\
\hline FC-4 (4+2) & $2.127 \mathrm{a}$ & $0.150 \mathrm{~b}$ & $2.378 \mathrm{ab}$ & 0.799 & 0.320 & 0.056 & $0.793 \mathrm{ab}$ & - & 54.100 & 43.733 & $279.933 \mathrm{~b}$ \\
\hline FC-5 (4+4) & $2.176 \mathrm{a}$ & $0.147 \mathrm{~b}$ & $2.050 \mathrm{~b}$ & 0.850 & 0.351 & 0.064 & $0.941 \mathrm{a}$ & - & 48.333 & 41.767 & $443.033 \mathrm{a}$ \\
\hline MEAN & 1.994 & 0.151 & 2.479 & 0.781 & 0.333 & 0.058 & 0.693 & - & 54.253 & 45.407 & 223.170 \\
\hline Zinc Factor $(B)$ & 2284 & $0156 \mathrm{~b}$ & $2346 \mathrm{~h}$ & 0886 a & 0335 & 0081 & 0621 & 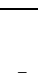 & 47100 & 41473 & 150.672 \\
\hline$-\mathrm{Zn}$ & 2.386 & $0.184 \mathrm{a}$ & $3.165 \mathrm{a}$ & $0.815 b$ & $\begin{array}{l}0.535 \\
0.319\end{array}$ & $\begin{array}{l}0.081 \\
0.159\end{array}$ & $\begin{array}{l}0.021 \\
0.743\end{array}$ & - & 46.600 & $\begin{array}{l}41.4 / 3 \\
50.677\end{array}$ & $\begin{array}{l}159.0 / 5 \\
160.223\end{array}$ \\
\hline$\% \mathrm{cv}(\mathrm{A})$ & 3.10 & 4.60 & 9.00 & 9.30 & 11.30 & 17.50 & 19.30 & - & 6.50 & 18.40 & 18.60 \\
\hline$\% \mathrm{cv}(\mathrm{B})$ & 2.00 & 3.60 & 4.70 & 1.30 & 6.40 & 82.50 & 5.20 & - & 13.30 & 12.30 & 6.00 \\
\hline \multicolumn{12}{|l|}{ Stat. sig. } \\
\hline A & $* *$ & $* *$ & $* *$ & ns & ns & ns & $*$ & - & ns & ns & $*$ \\
\hline B & $\mathrm{ns}$ & $*$ & $*$ & $*$ & ns & ns & ns & - & ns & ns & ns \\
\hline$A \times B$ & $\mathrm{~ns}$ & ns & ns & ns & ns & ns & ns & - & ns & ns & ns \\
\hline
\end{tabular}


Cord 2009, 25 (2)

Table 3. Continuation...

\section{Year 2001}

\begin{tabular}{|c|c|c|c|c|c|c|c|c|c|c|c|c|c|}
\hline \multirow{2}{*}{ TREATMENT } & \multicolumn{8}{|c|}{$(\% \mathrm{DM})$} & \multicolumn{5}{|c|}{$(\mathbf{p p m})$} \\
\hline & $\mathbf{N}$ & $\mathbf{P}$ & $\mathbf{K}$ & $\mathrm{Ca}$ & Mg & $\mathbf{N a}$ & $\mathrm{Cl}$ & $\mathbf{S}$ & B & $\mathbf{Z n}$ & Mn & $\mathbf{C u}$ & $\mathbf{F e}$ \\
\hline Fertilizer Level(A) & & & & & & & & & & & & & \\
\hline FC-1 $(1+0)$ & 2.62 & $0.21 \mathrm{c}$ & 2.74 & 0.99 & 0.36 & 0.02 & 0.17 & $0.16 \mathrm{c}$ & 52.20 & - & - & - & - \\
\hline $\mathrm{FC}-2(1+2)$ & 2.69 & $0.24 \mathrm{a}$ & 2.77 & 1.08 & 0.36 & 0.02 & 0.19 & $0.17 \mathrm{bc}$ & 51.30 & - & - & - & - \\
\hline $\mathrm{FC}-3(2+4)$ & 2.73 & $0.23 \mathrm{ab}$ & 2.67 & 1.15 & 0.36 & 0.02 & 0.19 & $0.18 \mathrm{ab}$ & 51.70 & - & - & - & - \\
\hline $\mathrm{FC}-4(4+2)$ & 2.62 & $0.22 \mathrm{bc}$ & 2.51 & 1.18 & 0.33 & 0.02 & 0.21 & $0.19 \mathrm{a}$ & 60.60 & - & - & - & - \\
\hline FC-5 (4+4) & 2.70 & $0.24 \mathrm{a}$ & 2.71 & 1.08 & 0.33 & 0.02 & 0.24 & $0.19 \mathrm{a}$ & 56.70 & - & - & - & - \\
\hline Zinc Factor (B) & & & & & & & & & & & & & \\
\hline$+\mathrm{Zn}$ & 2.69 & 0.23 & 2.71 & 1.07 & 0.35 & 0.02 & 0.20 & 0.18 & 53.80 & & & & \\
\hline$-\mathrm{Zn}$ & 2.66 & 0.23 & 2.64 & 1.11 & 0.35 & 0.02 & 0.20 & 0.17 & 55.20 & & & & \\
\hline$\% \mathrm{cv}(\mathrm{A})$ & 7.80 & 6.30 & 9.20 & 17.60 & 9.00 & 15.90 & 18.70 & 8.90 & 19.20 & & & & \\
\hline$\% \mathrm{cv}(\mathrm{B})$ & 4.60 & 8.60 & 8.20 & 11.70 & 9.50 & 14.30 & 20.60 & 8.10 & 7.90 & & & & \\
\hline Stat. sig. & & & & & & & & & & & & & \\
\hline $\begin{array}{l}\text { A } \\
\text { B }\end{array}$ & $\begin{array}{l}\mathrm{ns} \\
\mathrm{ns}\end{array}$ & ns & $\begin{array}{l}\mathrm{ns} \\
* *\end{array}$ & $\begin{array}{l}\text { ns } \\
\text { ns }\end{array}$ & $\begin{array}{l}\mathrm{ns} \\
\mathrm{ns}\end{array}$ & $\begin{array}{l}\text { ns } \\
\text { ns }\end{array}$ & $\begin{array}{l}\text { ns } \\
\text { ns }\end{array}$ & $* *$ & $\begin{array}{l}\text { ns } \\
\text { ns }\end{array}$ & & & & \\
\hline$A \times B$ & ns & ns & $\mathrm{ns}$ & $\mathrm{ns}$ & ns & ns & ns & ns & ns & & & & \\
\hline
\end{tabular}

\section{Year 2004}

\begin{tabular}{|c|c|c|c|c|c|c|c|c|c|c|c|c|c|}
\hline \multirow{2}{*}{ TREATMENT } & \multicolumn{8}{|c|}{ (\% DM) } & \multicolumn{5}{|c|}{$(\mathbf{p p m})$} \\
\hline & $\mathbf{N}$ & $\mathbf{P}$ & $\mathbf{K}$ & $\mathbf{C a}$ & Mg & $\mathbf{N a}$ & $\mathrm{Cl}$ & $\mathbf{S}$ & $\mathbf{B}$ & $\mathbf{Z n}$ & Mn & $\mathbf{C u}$ & $\mathbf{F e}$ \\
\hline $\begin{array}{l}\text { A. Without Zn } \\
\text { FC-1 }(1+0)\end{array}$ & 2.55 & 0.19 & 2.25 & 1.12 & 0.31 & 0.04 & 0.16 & 0.19 & $45.7 \mathrm{~b}$ & 25.1 & 59.1 & 10.6 & 178.5 \\
\hline $\mathrm{FC}-2(1+2)$ & 2.68 & 0.22 & 2.28 & 1.16 & 0.27 & 0.04 & 0.19 & 0.20 & $58.2 \mathrm{a}$ & 24.8 & 71.9 & 9.4 & 158.2 \\
\hline FC-3 $(2+4)$ & 2.71 & 0.19 & 2.36 & 1.33 & 0.31 & 0.35 & 0.24 & 0.18 & $44.1 \mathrm{~b}$ & 27.9 & 76.8 & 10.8 & 173.1 \\
\hline Stat. Sign. & $\mathrm{ns}$ & $\mathrm{ns}$ & ns & ns & ns & $\mathrm{ns}$ & $\mathrm{ns}$ & ns & $* *$ & ns & ns & ns & ns \\
\hline C.V. $(\%)$ & 2.7 & 9.4 & 8.6 & 17.4 & 7.0 & 21.5 & 27.9 & 4.3 & 6.0 & 6.5 & 17.8 & 9.8 & 21.4 \\
\hline B. With Zn & & & & & & & & & & & & & \\
\hline FC-1 $(1+0)$ & $2.53 \mathrm{~b}$ & 0.19 & 2.40 & 0.84 & 0.25 & 0.04 & 0.18 & 0.19 & 43.9 & 35.7 & 56.7 & $9.7 \mathrm{~b}$ & 119.1 \\
\hline FC-2 $(1+2)$ & $2.46 \mathrm{~b}$ & 0.20 & 2.55 & 0.86 & 0.28 & 0.04 & 0.19 & 0.20 & 45.0 & 27.2 & 53.4 & $8.8 \mathrm{~b}$ & 100.2 \\
\hline FC-3 $(2+4)$ & $2.73 \mathrm{a}$ & 0.21 & 2.52 & 0.81 & 0.26 & 0.04 & 0.25 & 0.19 & 44.6 & 31.3 & 63.4 & $11.3 \mathrm{a}$ & 112.4 \\
\hline Stat. Sign. & & ns & ns & ns & ns & ns & ns & ns & ns & ns & ns & ns & ns \\
\hline C.V. (\%) & 3.5 & 4.6 & 5.7 & 11.9 & 19.1 & 21.6 & 34.4 & 7.3 & 12.2 & 34.7 & 14.8 & 9.8 & 14.9 \\
\hline
\end{tabular}




\begin{tabular}{|c|c|c|c|c|c|c|c|c|c|c|c|}
\hline \multirow{2}{*}{ TREATMENT } & \multicolumn{8}{|c|}{ \% Dry Matter } & \multicolumn{3}{|c|}{ mg/kg dry matter } \\
\hline & $\mathbf{N}$ & $\mathbf{P}$ & $\mathbf{K}$ & $\mathbf{C a}$ & Mg & $\mathbf{N a}$ & $\mathbf{C l}$ & $\mathbf{S}$ & $\mathbf{B}$ & $\mathbf{Z n}$ & Mn \\
\hline \multicolumn{12}{|l|}{ A. Without Zn } \\
\hline FC-1 $(1+0)$ & 2.01 & 0.18 & 2.22 & $0.68 \mathrm{~b}$ & 0.31 & 0.05 & 0.18 & 0.19 & 56.1 & $22.9 \mathrm{c}$ & 52.2 \\
\hline FC-2 (1+2) & 2.01 & 0.20 & 2.39 & $1.02 \mathrm{a}$ & 0.27 & 0.05 & 0.23 & 0.21 & 58.4 & $27.0 \mathrm{a}$ & 47.8 \\
\hline FC-3 (2+4) & 2.05 & 0.18 & 2.27 & $1.05 \mathrm{a}$ & 0.30 & 0.05 & 0.22 & 0.20 & 61.9 & $24.6 \mathrm{~b}$ & 63.9 \\
\hline Stat. Sign. & ns & ns & ns & $*$ & ns & ns & ns & ns & ns & $* *$ & ns \\
\hline C.V. (\%) & 4.7 & 9.6 & 9.1 & 14.7 & 9.6 & 9.6 & 12.5 & 9.3 & 9.6 & 2.9 & 12.3 \\
\hline \multicolumn{12}{|l|}{ B. With Zn } \\
\hline FC-1 (1+0) & 2.49 & 0.20 & 2.40 & 0.63 & 0.30 & 0.30 & 0.24 & 0.20 & 47.9 & 25.9 & 55.7 \\
\hline FC-2 $(1+2)$ & 2.16 & 0.22 & 2.23 & 0.74 & 0.30 & 0.30 & 0.23 & 0.22 & 51.4 & 25.2 & 55.3 \\
\hline FC-3 (2+4) & 2.23 & 0.20 & 2.27 & 0.76 & 0.28 & 0.28 & 0.27 & 0.20 & 51.4 & 24.9 & 56.6 \\
\hline Stat. Sign. & ns & ns & ns & ns & ns & ns & ns & ns & ns & ns & ns \\
\hline C.V. $(\%)$ & 12.5 & 8.2 & 10.6 & 26.2 & 10.0 & 10.4 & 11.6 & 2.0 & 9.9 & 8.4 & 10.6 \\
\hline \multicolumn{12}{|l|}{ Ave. Adeq. } \\
\hline Level $^{a}$ & 2.70 & 0.20 & 2.00 & 1.35 & 0.35 & 0.03 & 0.25 & 0.19 & 54 & 30 & 65 \\
\hline
\end{tabular}

a Magat and Mantiqulla, 2005

F. Year 2006

\begin{tabular}{|c|c|c|c|c|c|c|c|c|c|c|c|c|c|}
\hline \multirow{2}{*}{ TREATMENT } & \multicolumn{8}{|c|}{ \% Dry Matter } & \multicolumn{5}{|c|}{ mg/kg dry matter } \\
\hline & $\mathbf{N}$ & $\mathbf{P}$ & $\mathbf{K}$ & $\mathbf{C a}$ & Mg & $\mathbf{N a}$ & $\mathbf{C l}$ & $\mathbf{S}$ & $\mathbf{B}$ & Zn & Mn & $\mathbf{C u}$ & $\mathbf{F e}$ \\
\hline \multicolumn{14}{|l|}{ A. Without Zn } \\
\hline FC-1 $(1+0)$ & 2.69 & 0.19 & 2.48 & 1.21 & $0.30 \mathrm{~b}$ & 0.76 & - & 0.18 & 42.3 & 17.3 & 30.7 & 5.9 & 66.0 \\
\hline FC-2 (1+2) & 2.78 & 0.19 & 2.45 & 1.15 & $0.30 \mathrm{~b}$ & 0.71 & - & 0.19 & 50.3 & 18.8 & 31.4 & 6.3 & 72.8 \\
\hline $\mathrm{FC}-3(2+4)$ & 2.75 & 0.17 & 2.28 & 1.33 & $0.36 \mathrm{a}$ & 0.73 & - & 0.20 & 56.7 & 17.9 & 37.6 & 6.6 & 67.5 \\
\hline Stat. Sign. & ns & ns & ns & ns & $*$ & ns & & ns & ns & ns & ns & $\mathrm{ns}$ & ns \\
\hline C.V. (\%) & 7.7 & 8.4 & 9.5 & 14.1 & 7.2 & 5.2 & & 11.1 & 14.3 & 8.0 & 13.2 & 16.1 & 8.6 \\
\hline \multicolumn{14}{|l|}{ B. With Zn } \\
\hline FC-1 $(1+0)$ & 2.77 & 0.17 & 2.35 & 1.30 & 0.30 & 0.07 & - & 0.19 & 54.1 & 20.8 & 35.5 & 6.8 & 75.6 \\
\hline $\mathrm{FC}-2(1+2)$ & 2.70 & 0.17 & 2.26 & 1.30 & 0.30 & 0.07 & - & 0.21 & 54.2 & 22.0 & 30.4 & 7.6 & 88.3 \\
\hline FC-3 $(2+4)$ & 2.88 & 0.18 & 2.27 & 1.27 & 0.32 & 0.07 & - & 0.18 & 55.0 & 21.7 & 40.0 & 7.2 & 77.4 \\
\hline Stat. Sign. & ns & $\mathrm{ns}$ & ns & ns & $\mathrm{ns}$ & ns & & $\mathrm{ns}$ & ns & ns & ns & ns & ns \\
\hline C.V. (\%) & 5.5 & 14.1 & 13.5 & 17.0 & 9.9 & 5.3 & & 8.9 & 9.4 & 26.6 & 16.5 & 16.0 & 17.7 \\
\hline
\end{tabular}


Cord 2009, 25 (2)

G. Year 2007

\begin{tabular}{|c|c|c|c|c|c|c|c|c|c|c|c|c|c|}
\hline \multirow{2}{*}{ TREATMENT } & \multicolumn{8}{|c|}{ \% Dry Matter } & \multicolumn{5}{|c|}{ mg/kg dry matter } \\
\hline & $\mathbf{N}$ & $\mathbf{P}$ & $\mathbf{K}$ & $\mathbf{C a}$ & Mg & $\mathbf{N a}$ & $\mathrm{Cl}$ & $\mathbf{S}$ & B & $\mathbf{Z n}$ & Mn & $\mathbf{C u}$ & $\mathbf{F e}$ \\
\hline \multicolumn{14}{|l|}{ A. Without Zn } \\
\hline FC-1 $(1+0)$ & 1.417 & 0.158 & 2.365 & 1.073 & 0.328 & 0.064 & 0.270 & 0.218 & 44.23 & 19.87 & 40.17 & 7.63 & 76.97 \\
\hline FC-2 (1+2) & 1.351 & 0.195 & 2.282 & 1.296 & 0.331 & 0.068 & 0.215 & 0.226 & 50.53 & 21.97 & 41.73 & 7.03 & 76.83 \\
\hline FC-3 (2+4) & 1.459 & 0.203 & 2.288 & 1.145 & 0.361 & 0.065 & 0.307 & 0.209 & 53.47 & 21.50 & 37.77 & 8.23 & 70.37 \\
\hline Stat. Sign. & ns & ns & ns & $\mathrm{ns}$ & ns & $\mathrm{ns}$ & ns & ns & ns & ns & ns & ns & ns \\
\hline C.V. $(\%)$ & 6.6 & 20.3 & 12.9 & 18.7 & 2.7 & 4.5 & 18.9 & 5.5 & 7.1 & 11.3 & 12.8 & 6.4 & 14.1 \\
\hline \multicolumn{14}{|l|}{ B. With Zn } \\
\hline FC-1 $(1+0)$ & 1.295 & 0.187 & 2.298 & 1.445 & 0.363 & 0.065 & 0.258 & 0.198 & 69.73 & 20.20 & $36.73 \mathrm{ab}$ & 6.17 & 77.53 \\
\hline FC-2 (1+2) & 1.303 & 0.187 & 2.275 & 1.122 & 0.337 & 0.064 & 0.258 & 0.192 & 62.53 & 14.33 & $31.7 \mathrm{~b}$ & 7.40 & 58.73 \\
\hline FC-3 (2+4) & 1.433 & 0.206 & 2.264 & 1.172 & 0.349 & 0.073 & 0.2 & 0.201 & 73.20 & 22.10 & $40.33 \mathrm{a}$ & 7.23 & 86.30 \\
\hline Stat. Sign. & ns & ns & $\mathrm{ns}$ & $\mathrm{ns}$ & ns & $\mathrm{ns}$ & ns & ns & $\mathrm{ns}$ & ns & $*$ & ns & ns \\
\hline C.V. $(\%)$ & 3.6 & 9.2 & 7.9 & 27.4 & 5.0 & 8.9 & 36.9 & 5.2 & 9.9 & 23.1 & 7.4 & 9.9 & 20.9 \\
\hline
\end{tabular}


aeration and internal drainage). However, after four years of ISFM (IF +OF) application, in 1997, the SBD of the lanzones area (in Table 4) trees was significantly affected. The FC-5 (4 IF + 4 OF: $1.26 \mathrm{~kg} \mathrm{IF}+2.5 \mathrm{~kg} \mathrm{OF}$ ) had the lowest (best) soil bulk density of $1.38 \mathrm{~g} / \mathrm{cc}$ vs. $1.55 \mathrm{~g} / \mathrm{cc}$ with FC-3 (2 IF +4 OF), implying higher porosity, better aeration and soil tilt with higher rates of organic fertilizer application over time.

Appreciably, with time, the average soil bulk density of the areas within coconut and lanzones stands decreased (coconut: 1.7 BD, $1995 ; 1.35 \mathrm{BD}, 1997,1.1 \mathrm{BD}, 2007)$. In the case of lanzones these were: $1.79 \mathrm{BD}, 1995 ; 1.38 \mathrm{BD}$, 1997; and 1.1 BD, 2007, indicating an improvement of this important soil physical property with time (15 years). The accumulation of significant quantities of plant-based organic materials (lanzones litters and coconut husks, and other waste materials on the ground) very likely contributed also to the build up and accumulation organic materials, later converted to soil organic matter (SOM), resulting in high soil humus content in this coconut + lanzones agroecosystem, and finally improving the soil BD in the soil environment of the agro-ecosystem or cropping system Moreover, this improvement in soil physical conditions enhances root respiration, aeration and its development, thus favoring efficient intake of soil water and soil nutrients for general crop growth and yield. (Mangawang, 1993 in Secretaria and Maravilla, 1997).

\section{Soil chemical properties under ISFM of the coconut + lanzones agro-ecosystem}

Soil Acidity $(\mathrm{pH})$. Two years after the initial (first) application of fertilizer treatments, the soil $\mathrm{pH}$ (acidity) within the root environments of the coconut and the lanzones trees did not vary significantly (Table 5). However, between the two soil rhizospheres, the one in the coconut areas $(\mathrm{pH} 4.9)$ was more acidic than that of the lanzones areas ( $\mathrm{pH}$ 5.6). This means that the low to high rates of inorganic (IF) or mineral fertilizer application [FC-1 to FC-5): $1-4 \mathrm{~kg} \mathrm{IF} /$ tree/year for coconut] had similar soil acidities; while for the lanzones areas, the higher rates (FC-4 and FC-5): both with $1.50 \mathrm{~kg} \mathrm{IF} /$ tree $/ \mathrm{yr}$, tended to make the lanzones soil more acidic compared to lower and moderate rates of IF $(0.38-0.75 \mathrm{~kg}$ $\mathrm{IF} /$ tree/year) under this coconut + lanzones agro-ecosystem. Clearly, the higher rate of IF and lower rate of $\mathrm{OF}$ (as in FC 4) application resulted to more acidic soil ( $\mathrm{pH}$ : 5.3, coconut: and $\mathrm{pH} 4.1$, lanzones areas), with $4 \mathrm{~kg} \mathrm{IF}+2 \mathrm{~kg}$ $\mathrm{OF} /$ year application on coconut. On the other hand, the highest rate of both the IF and the OF (FC-5) increased the soil $\mathrm{pH}$ to a higher level ( $\mathrm{pH}$ 5.5-coconut; $\mathrm{pH}$ 4.5- lanzones). This study showed that the application of higher rates of organic fertilizers (OF) on both fruit tree lanzones and coconut tree tended to lower soil $\mathrm{pH}$ (increased soil acidity), particularly in cropping years sampled for $\mathrm{pH}$ in 1995 and 1997, respectively.

Influence of long-term application of inorganic multi-nutrient fertilizer on the soil fertility conservation of the coconut + lanzones agro-ecosystem

Generally, there was an insignificant change (or similarity) of benchmark soil $\mathrm{pH}$; compared to conditions as affected by the combination of inorganic (IF) and organic fertilizers (OF) over the long-term cropping shown in Figure 1 which indicated the $\mathrm{pHs}$ of the FCs (FC-1, FC-2 and FC-3) with increasing levels of IF and OF. In all sampling years (1995 -2007), the soil acidity measured by soil $\mathrm{pH}$ (in water) were similar in all FCs, even with the application of OF. Moreover, the application of gypsum as a component of the MNF (IF) likely contributed to higher soil exchangeable $\mathrm{Ca}$ (increased of 3-5 meq/100 soil) in the first four years of the coconut + lanzones fruit tree cropping, but not in the long term cropping periods as in 2003 and 2007 of which the crops where applied with the commercially processed 14-5-20-15.5(Cl)-4.5(S)-0.02(B) which contains only $10.8 \% \mathrm{CaO}(7.7 \% \mathrm{Ca})$. On soil acidity, the sustained $\mathrm{pH}$ above 5, with the long term cropping

Table 4. Bulk density of soil sample taken from coconut and lanzones areas at different time periods (1995, 1997, 2007). PCA-DRC 


\begin{tabular}{|l|c|c|c|c|c|c|}
\hline \multirow{2}{*}{ TREATMENT } & \multicolumn{2}{|c|}{ Bulk density (g/cc)-1995 } & \multicolumn{2}{c|}{ Bulk density (g/cc)-1997 } & \multicolumn{2}{c|}{ Bulk density (g/cc)-2007 } \\
\cline { 2 - 7 } & Coconut & Lanzones & Coconut & Lanzones & Coconut & Lanzones \\
\hline FC-1 (1+1) & 1.71 & 1.78 & 1.35 & $1.49 \mathrm{ab}$ & 1.1 & 1.0 \\
FC-2 (1+2) & 1.69 & 1.77 & 1.33 & $1.47 \mathrm{ab}$ & 1.0 & 1.1 \\
FC-3 (2+4) & 1.72 & 1.80 & 1.37 & $1.55 \mathrm{a}$ & 1.1 & 1.1 \\
FC-4 (4+2) & 1.69 & 1.82 & 1.37 & $1.49 \mathrm{ab}$ & 1.0 & 1.1 \\
FC-5 (4+4) & 1.68 & 1.79 & 1.35 & $1.38 \mathrm{~b}$ & 1.1 & 1.1 \\
MEAN & 1.7 & 1.79 & 1.35 & 1.48 & 1.1 & 1.1 \\
Stat.sig. & $\mathrm{ns}$ & $\mathrm{ns}$ & $\mathrm{ns}$ & $*$ & $\mathrm{~ns}$ & $\mathrm{~ns}$ \\
c.v. $(\%)$ & 4.1 & 3.1 & 4.0 & 3.6 & 7.8 & 3.6 \\
\hline
\end{tabular}

* - significant at $5 \%$

ns - not significant

Table 5. Soil pH soil samples taken from coconut and lanzones areas at different time period, PCADRC

\begin{tabular}{|l|c|c|c|c|}
\hline \multirow{2}{*}{ TREATMENT } & \multicolumn{2}{|c|}{ Yr 1995 } & Yr 1997 & Yr 2007 \\
\cline { 2 - 4 } FC-1 (1+0) & Coconut $^{1}$ & Lanzones $^{2}$ & Coconut & Coconut \\
FC-2 (1+2) & 4.9 & 5.8 & 4.75 & 5.40 \\
FC-3 (2+4) & 5.0 & 5.8 & 4.75 & 5.40 \\
FC-4 (4+2) & 4.9 & 5.8 & 4.65 & 5.40 \\
FC-5 (4+4) & 5.1 & 5.3 & 4.10 & - \\
MEAN & .4 .9 & 5.5 & 4.47 & - \\
Stat.sig. & 4.9 & 5.6 & 4.5 & \\
\cline { 2 - 4 } c.v. $(\%)$ & $\mathrm{ns}$ & $\mathrm{ns}$ & $\mathrm{ns}$ & $\mathrm{n}$ \\
\hline
\end{tabular}

${ }^{1}$ soil sample taken one (1) meter from the coconut tree

${ }^{2}$ soil sample taken one $\mathrm{ft}$ from the lanzones tree

applied with the MNF (all FCs observed) was likely influenced by the $7.7 \% \mathrm{Ca}$, a cationic nutrient of the IF.
The soil bulk density or SBD (an index of the soil physical attribute), clearly tended to decrease or improve the soil structure and porosity over the cropping period as measured 
in years 1995, 1997 and 2007 for the three observed FCs (Figure 2). Apparently, the SBD of the coconut + lanzones fruit tree ecosystem did not vary among the fertilizer combinations (FCs) with different parts or ratio of IF and OF. This indicates that $\mathrm{OF}$ fertilizers applied even at higher rates of 4 parts $\mathrm{OF}$ did not influence the SBD of the coconut + lanzones agro-ecosystem.

From years 2003 to 2007, the general effects in soil organic carbon (SOC) of the different FCs could be considered a quadratic trend (plateaued in 2003) and a moderate decrease four years later in 2007 (Figure 3). This indicates that significant carbon storage in the soil had taken place with FCs application and the FC-1 (lowest rate of IF w/o OF) reached similar levels to that with higher rates of IF and OFs (FC-2 + FC-3). In recent years, the importance of $\mathrm{CO}_{2}$ sequestration by plants as coconuts (Roupsard 2004) via the biomass generation which is eventually stored or buried in the soil as SOC (for 15 - 100 years) and in the form of more dynamic (less unstable) soil organic matter (SOM) had been recognized extensively in relation to the mitigation of global climate change and warming (Goh 2005). He mentioned that the soil contains about three times more $\mathrm{C}$ than in plants and twice that of the atmosphere, in which the direct sequestration of $\mathrm{C}$ takes place via plant photosynthetic process of the atmospheric $\mathrm{CO}_{2}$ into crop biomass $\mathrm{C}$.

The estimated above ground biomass production of a mature Laguna Tall variety was $152 \mathrm{~kg} / \mathrm{tree} / \mathrm{yr}$ (UPLB and PCA 2002 cited Eroy et al., unpub.). While the annual $\mathrm{CO} 2$ fixed in coconut roots and trunk had been estimated at $12.81 \mathrm{t} \mathrm{CO} 2$ per ha under a situation in which fronds, husks, shell and bunch peduncle are exported out of the field) (Eroy et al 1999).

The more dynamic SOM, a soil property strongly affected by changes in soil biological and climatic factors (temperature and moisture) and the soil available $\mathrm{P}$ followed similar trends highest in 2003 and moderately decreased four years later in 2007 (final cropping). And as mentioned in for the other soil properties, the FCs influenced on SOM did not vary significantly, even at higher levels of IF and OF (Figures 4 and 5).

As regards to the soil nutrients $\mathrm{K}$ and $\mathrm{Na}$ (as exchangeable or more plant-available form), these cations general increased over the years (1993-2007), but the different FCs even at higher rates of IF and OF did not vary in soil nutrient levels (Figures 6 and 9). These results clearly indicate the build up over time in the soil of these cationic nutrients under the coconut + lanzones agro-ecosystem long-term cropping. The increase in soil $\mathrm{Na}$ over time may be attributed to the accumulation of recycled $\mathrm{Na}$ from the recyclable biomass, but for the macronutrient $\mathrm{K}$, tits build up in the soil are likely attributed from the residual soil $\mathrm{K}$ from the IF application of the ISFM of the agroecosystem which has $20 \% \mathrm{~K}_{2} \mathrm{O}$ in the fertilizer grade applied and from also the recyclable $\mathrm{K}$ from the annual biomass produced by the agroecosystem over the years.

However, the other exchangeable soil cationic nutrients $\mathrm{Ca}$ and $\mathrm{Mg}$ (Figures 7 and 8 generally tended to decrease over time ( 15 years cropping), but with that of exchangeable $\mathrm{Ca}$ noted to increased after 4 years from the initial applications of the three FCs, even at the lowest rate of the multi-nutrient $14(\mathrm{~N})-5\left(\mathrm{P}_{2} \mathrm{O}_{5}\right)$ $20\left(\mathrm{~K}_{2} \mathrm{O}\right)-15.5(\mathrm{Cl})-4.5(\mathrm{~S})-0.02(\mathrm{~B})$, the IF fertilizer combination component. Also, the influence on the these soil nutrients of three FCs applied were almost similar, suggesting there is no advantage of applying higher rates of inorganic fertilizer (IF) and the addition of external source of organic fertilizers (OF) other than the ones naturally generated by the coconut + agro-ecosystem thru its biomass production over the 15 years long-term cropping.

Figure 1. Soil pH as affected by fertilizer combi lanzones cropping system, PCA-DRC, 
Figure 2. Soil Bulk density as affected by three fertilizer treatments under coconut-lanzones cropping system, PCA-DRC, 1993-2007

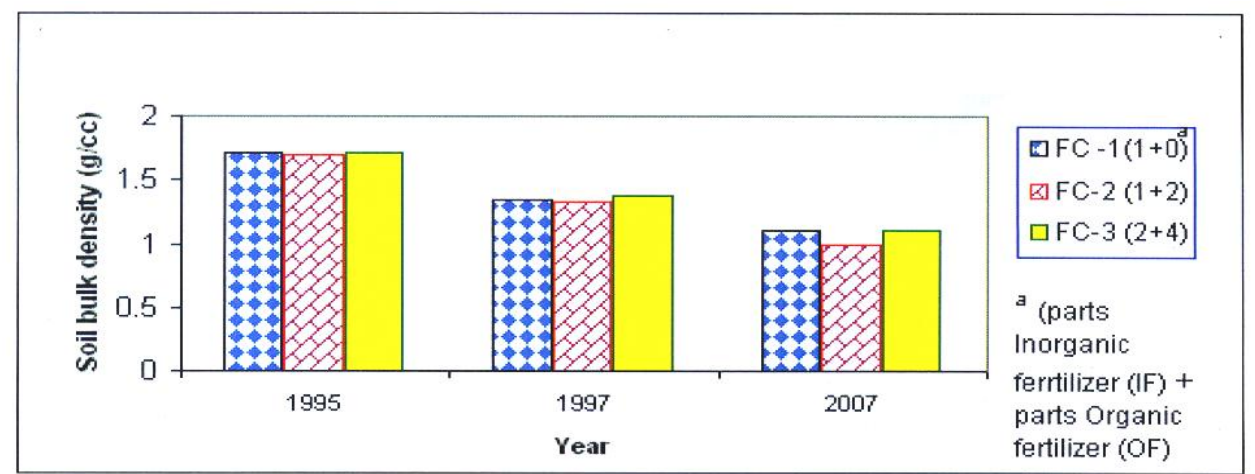

Figure 3. Percent (5) Organic Carbon as affected by three fertilizer combinations under coconut + lanzones cropping system, PCA-DRC, 1993-2007

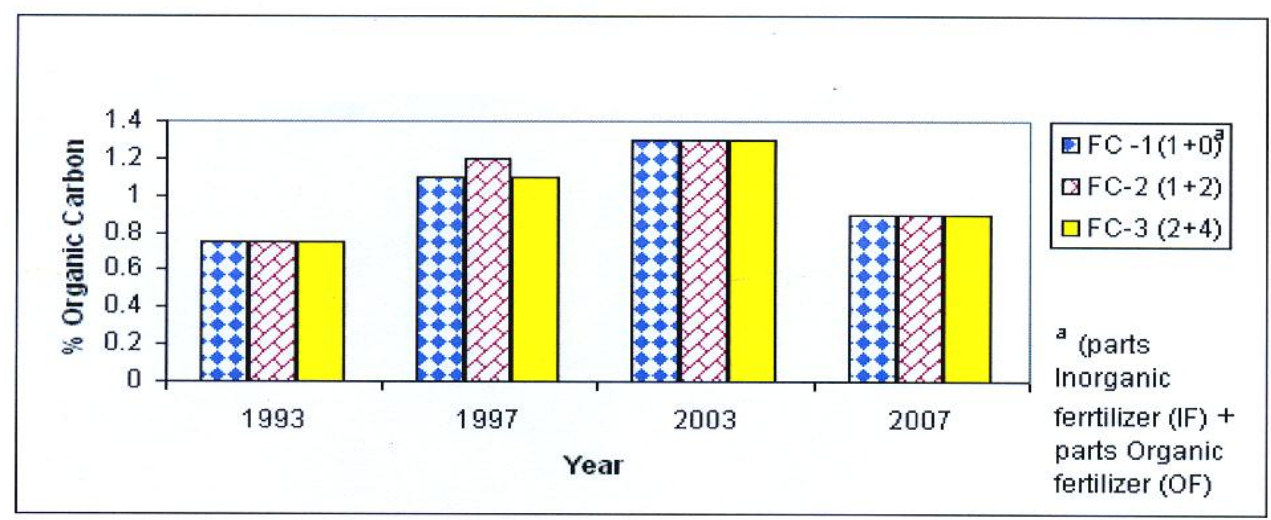

Figure 4. Percent (\%) Organic matter (\% O.M.) as affected by three fertilizer combinations under coconut + lanzones cropping system, PCA-DRC, 1993-2007

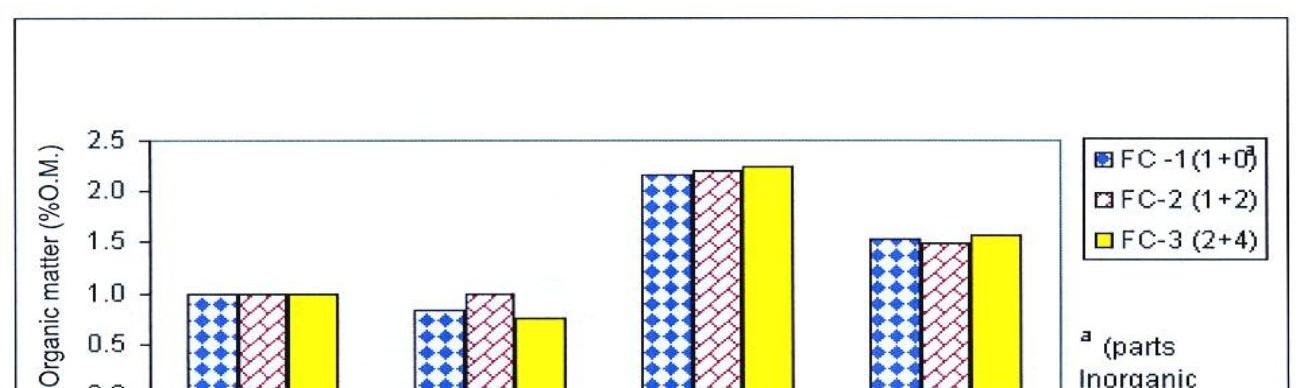


Figure 5. Soil phosphorus $(P)$ content as affected by three fertilizer combinations under coconut + lanzones cropping system, PCA-DRC, 1993-2007

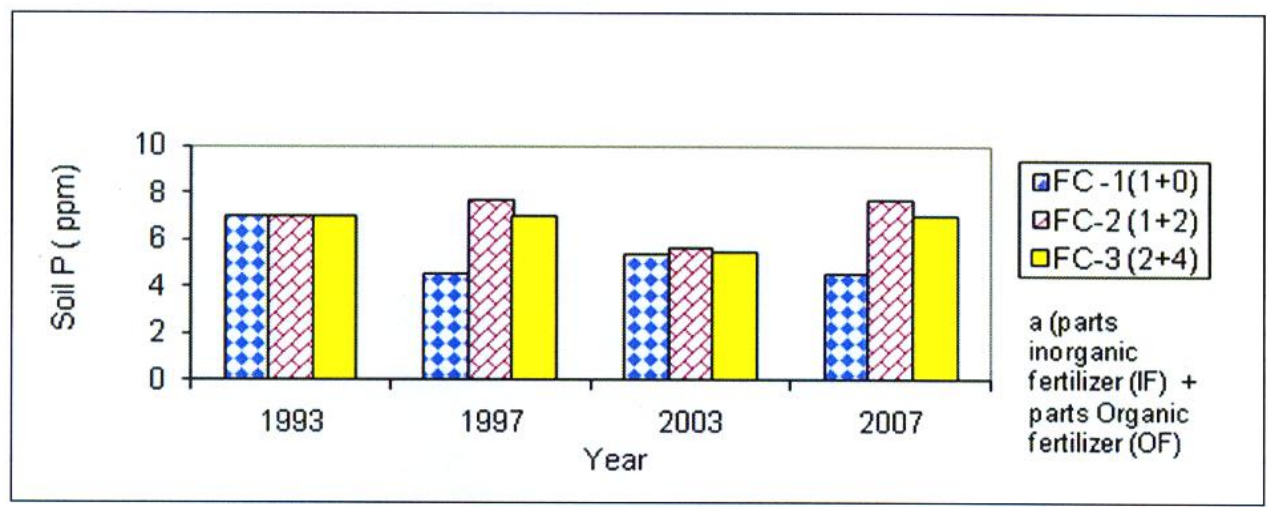

Figure 6. Soil exchangeable potassium $-\mathrm{K}(\mathrm{meq} / 100 \mathrm{~g}$ soil) as affected by three fertilizer combinations under coconut + lanzones cropping system, PCA-DRC, 1993-2007

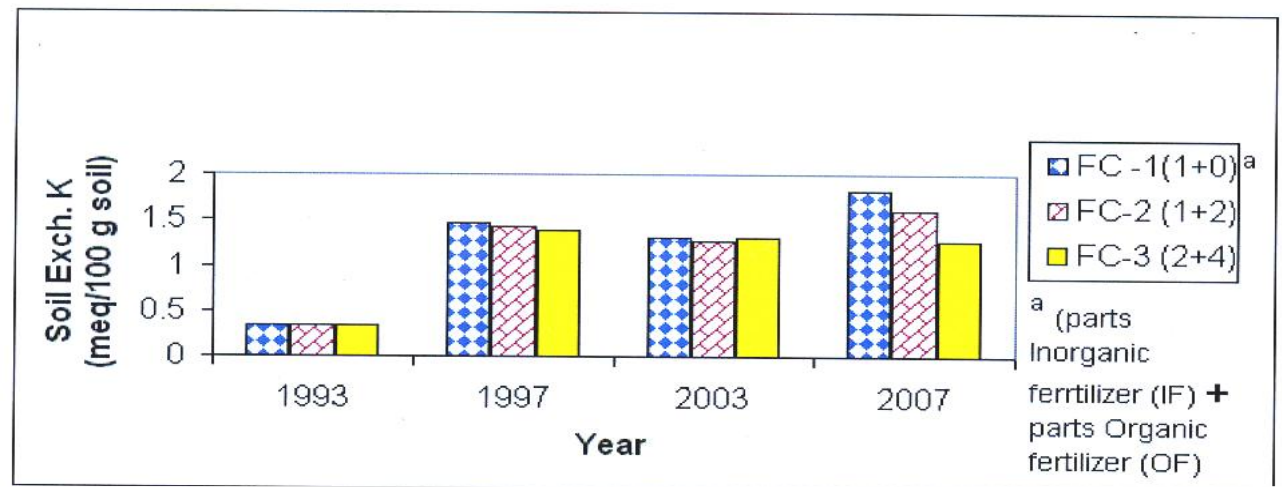

Figure 7. Soil exch. Calcium -Ca (meq/100 g soil) as affected by three fertilizer combinations under coconut+lanzones cropping system, PCA-DRC, 1993-2007

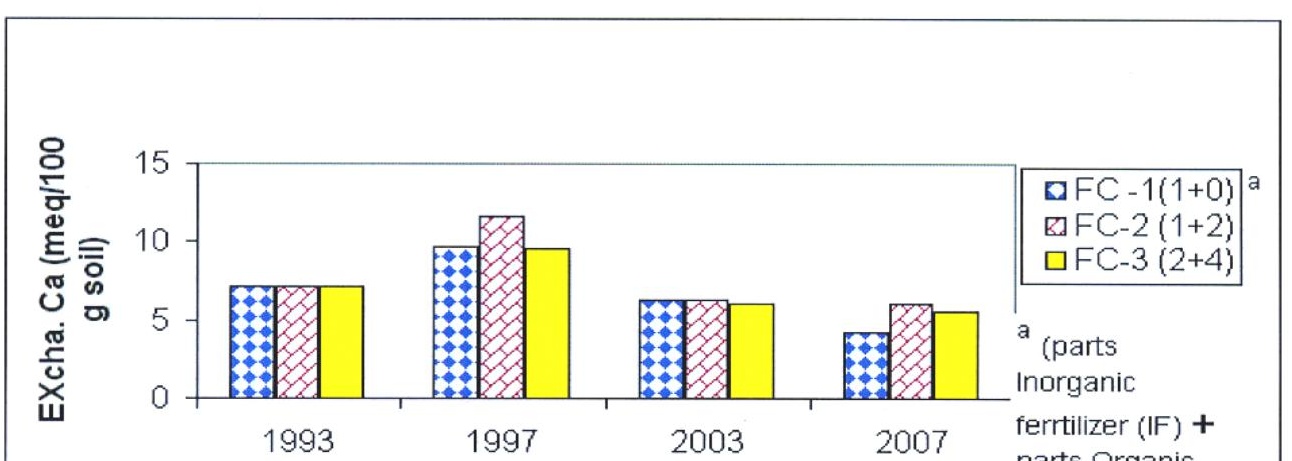


Cord 2009, 25 (2)

Figure 8. Soil exch. Magnesium -Mg (meq/100 g soil) as affected by three fertilizer combinations under coconut+lanzones cropping system, PCA-DRC, 1993-2007

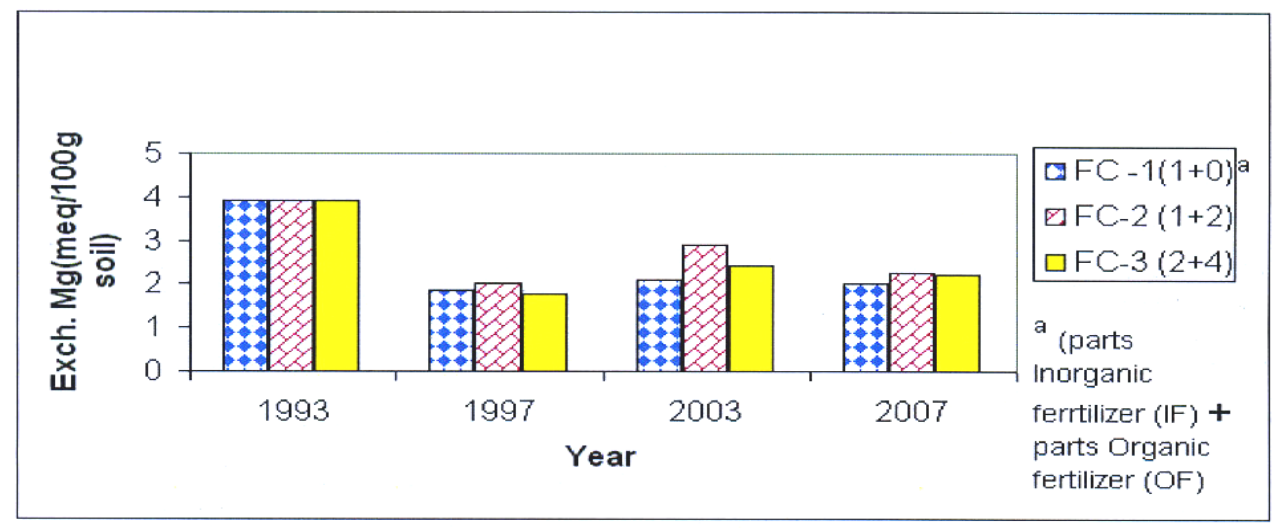

Figure 9. Soil exch. Sodium $-\mathrm{Na}(\mathrm{meq} / 100 \mathrm{~g}$ soil) as affected by three fertilizer combinations under coconut+lanzones cropping system, PCADRC, 1993-2007

Therefore

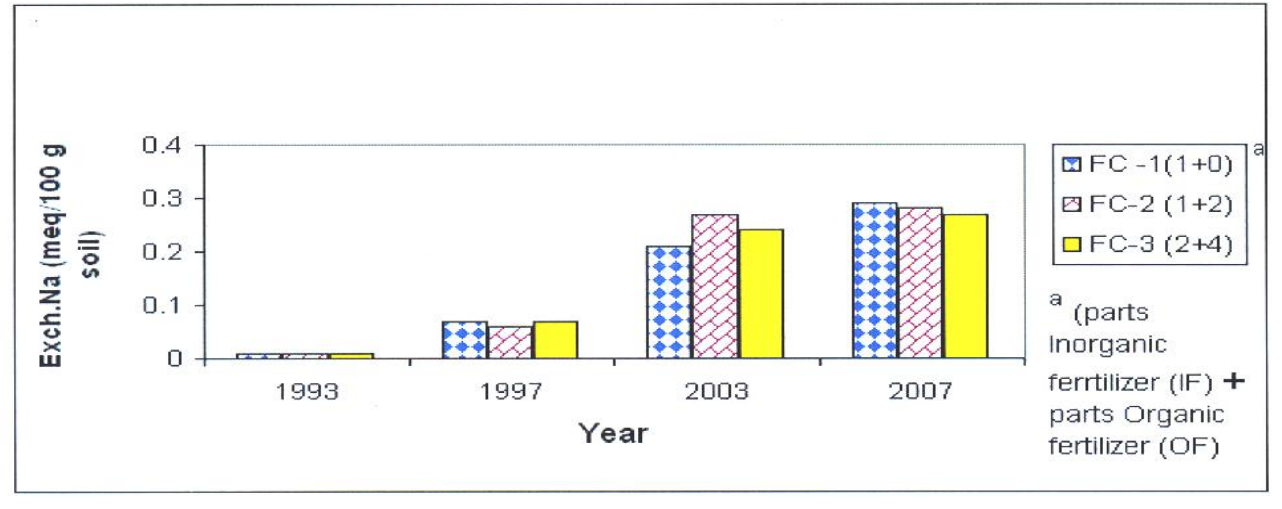

eed

has

ical

that the applied

and $B$ from the $I F$ and $U F$ sources were l1kely utilized to a great extent by the crop via soil nutrient absorption/uptake for high and sustained yields of the coconut and lanzones crops over the years of the agro-ecosystem. Moreover, the remarkable productivity and profitability of this agro-ecosystem even a low levels of fertilizer production inputs as demonstrated in this long 15 growers, and the Philıppine agriculture, particularly in the optimization of the utilization of coconut lands in the country, following a productive, environment-protective and sustainable integrated soil fertility management or ISFM. 


\section{Effect of rainfall on the performance of 'LAGT' coconuts}

In this long-term coconut-based ISFM cropping study, with a fairly low benchmark annual yield level of $1.6 \mathrm{t}$ copra ( 8,890 nuts) per ha, a remarkable yield performance of the coconut crop, even with the intercrop lanzones fruit trees was favored with highly adequate uniformly distributed rainfall of 2,.500 - 3,.050 mm/year (Annex Table 1). This was so, particularly, in last six years cropping years, with very satisfactory rainfall distribution pattern (at least 9 wet months and not more than three dry months) at this inland-upland experimental area situated at inland-upland Davao City, Southern Mindanao). This condition is similar to an extensive area of several thousands hectares of volcanic-residual lands around the foot-slopes of Mt. Apo where coconut and diverse fruit crops are grown under mono-cropping and intercropping systems. In years 2000 and 2001, an exceptional annual average yield of 5 tons/ha had been achieved at PCA-Davao Research Center, particularly in this study area. This was highly attributed to the highly ideal growing conditions during those periods highly favored by the optimum rainfall conditions (without water deficits in these years), after a devastating long drought during the period October 1997 - April 1998 (national annual output of coconut significantly dropped to $1.34 \mathrm{M}$ metric tons in 1999 from 2.4 M tons in 1996).

This means that the consistent very high coconut productivity (over $5 \mathrm{t}$ copra/ha) obtained in this ISFM agro-ecosystem of the coconut + lanzones long term cropping was the outcome of the synergism of optimum water and nutrient supply of the agro-ecosystem -------- achieved even at the low application rates of the inorganic multi-nutrient ( $\mathrm{N}, \mathrm{P}, \mathrm{K}, \mathrm{Cl}, \mathrm{S}$ and $\mathrm{B}$ ) balanced fertilizer grade suitable for the coconut + fruit agro-ecosystem.

In this long-term ISFM study under the coconut + lanzones fruit tree agro-ecosystem, the lack of a clear direct positive response to application of organic fertilizer sources does not mean that there was no addition of plant-based organic materials/fertilizers as the organic matter and nutrient supply generated by the biomass from the coconut and lanzones agro-ecosystem had been likely substantial. Hence, under an ISFM of coconut-based farming system, the capability of the component intercrop (s) as the lanzones fruit tree in this long-term cropping should not be ignored, rather considered a significant source of valuable organic fertilizer inputs from the decomposition of the ecosystem natural litters and other crop residues inherent in the coconut + lanzones fruit tree agro-ecosystem for a profitable and sustainable farming.

\section{Conclusion and recommendation}

From the benchmark annual yield (prefertilizer application) of bearing stands of the Laguna Tall variety of $1.4-1.8 \mathrm{t}$ copra/ha it increased to 3 - 4 tons after 1-2 years from initial fertilizer application and remained at this level in the next 13 years at stable yields of $4 \mathrm{t} /$ ha. The non-significant difference in nut and copra yields of fertilizer combinations (FC's) in almost all years indicates that even with the application of $\mathrm{FC}-1$ (one $\mathrm{kg}$ of inorganic fertilizer with no organic fertilizer) or the lowest rate of the multi-nutrient fertilizer without organic fertilizer, annual yield over 3.5 tons copra per ha (or over 125 nuts per tree) was produced in most of years of production.

The improvement of coconut yield and highly productive lanzones fruiting stage in this cropping system could be due to the significant effect of fertilizer combinations on some important leaf nutrients such as $\mathrm{N}, \mathrm{P}, \mathrm{K}, \mathrm{Ca}, \mathrm{Cl}$ and $\mathrm{B}$.

Fertilizer treatments with organic fertilizer appeared to increase levels of soil organic matter, available $\mathrm{P}$ and exchangeable bases e.g. $\mathrm{K}, \mathrm{Ca}, \mathrm{Mg}$. The long term effect of organic fertilization have contributed to the better physical (bulk density) and better soil properties of lanzones soil environment, in general.

Hence, this long-term coconut + lanzones cropping (agro-ecosystem) showed clearly to be a productive and sustainable farming system. With proper integrated soil fertility management (ISFM) as a major component of the integrated 
crop management (ICM) using crop specific fertilizer as the PCA formulated multi-nutrient $14 \mathrm{~N}-5 \mathrm{P}-20 \mathrm{~K}-15 \mathrm{Cl}-4.5 \mathrm{~S}-0.02 \mathrm{~B}$ even at the lowest rate of fertilization which largely contributed to stable soils contributing to the high total productivity levels of the coconut land

The ecological and economic contributions of the lanzones fruit tree intercrop as an indirect source of organic fertilizers thru the agroecosystem had been shown in this long-term study. Moreover, findings of this long-term study opened the need to conduct further studies in understanding the quality and quantity of the recyclable biomass and available recyclable macro- and micro-nutrients generated in the widely practiced coconut + lanzones agroecosystem as an important aspects of integrated crop management (ICM) to optimize productivity and conserve our farmlands.

\section{Acknowledgement}

The researchers and authors of this completed $R \& D$ wish to express their profound gratitude to the following:

1) The PCA Management, particularly the Office of Deputy Administrator, Research, Development and Extension Branch (RDEB) Carlos B. Carpio for the logistical and moral support to this long term project;

2) The ATLAS Chemical and Fertilizer Company Inc (AFCI) Management for the commercial production of the PCA preformulated crop-specific multi-nutrient fertilizer grade 14-5-20 (w/ $0.02 \% \mathrm{~B}$, $15.5 \% \mathrm{Cl}, 4.5 \% \mathrm{~S}$ ) under the brand CocoGro, and providing this fertilizer grade starting 2004 for project use and substantial financial support for leaf and soil analyses;

3) The FERCHEMEX Company for providing the required commercial organic fertilizer (1993-1998) and the fertilizer materials $\left(\mathrm{NH}_{4} \mathrm{Cl}, \mathrm{KCl}\right.$, Rock Phosphate, Gypsum, $\mathrm{ZnSO}_{4}$ and borax) for the physically-blended 14-5-20-15 (Cl) - 4.5
(S)-0.02 (B) inorganic fertilizer (IF) used for the different FCs.

4) The PCA-Davao Research Center (DRC) Management for their consistent support, most especially to: (1) Ms. Marianita N. Eroy, Science Research Specialist II and Officer-in-Charge, Agronomy \& Soils Division (ASD) for her valuable support and guidance: and (2) Dr. Liberty $\mathrm{H}$. Canja, Sc. Research Specialist II, ASD for contributing her valuable expertise and assistance in the economic analysis of the coconut + lanzones fruit tree agroecosystem;

5) Ms. Carmelita D. Pabustan, Division Chief III, Plant and Soil Analysis Division-Plant Tissue Analysis Laboratory (PSAD-PTAL), PCA and her staff for the intensive and extensive leaf and soil analyses of submitted samples;

6) Mr. Edilberto G. Cuison, Utility Worker, and Mr. Salvador C. Abendan, Laboratory Aide, ASD and their support labor force for their extensive assistance covering all the vital experimental field and laboratory activities;

7) Ms. Maricel D.M. Francisco, Secretary, Office of the Manager, Agricultural Research Management Department, $\mathrm{RDEB}$, for her dedicated assistance in the final computer lay-outing of this report presentation; and

8) Above all, our Almighty God for blessing this original work and giving us wisdom and strength to undertake this 15-year long-term study so that we may be able to generate meaningful research findings for the social, ecological and economic benefits of the coconut farmers and other sectors of the Philippine Agriculture and the Coconut Industry.

\section{References}

Magat, S.S., Secretaria, M.I., Mantiquilla, J.A. and Margate, R.Z. 2009. Integrated Soil Fertility Management (ISFM) on Coconut + Lanzones (Lansium domesticum Corr.) 
Agro-ecosystem in Southern Mindanao, Philippines (1993-2007): with emphasis on the multi-nutrient coconut-specific mineral fertilizer*. Part I. Crop productivity, Quality and Profitability. Coconut Res. and Dev. J. (in press).

Magat, S.S. 1976. Soil and Leaf Analyses in relation to coconut yield. Phil. J. Coconut Studies 1(2): 1-12.

Magat, S.S. 1990. Growing conditions and growth habits of coconut in relation to coconut-based farming systems. Pp. 17 40. In: Coconut Based Farming Systems, S. de Silva (ed.). Jakarta, Indonesia: Asian and Pacific Coconut Community. 606 p.

Magat, S.S. 2007. A field guide: estimating the yield of coconuts, soil sampling and leaf sampling. Diliman Quezon City: Agricultural Research Management Department. RDEB, Philippine Coconut Authority. 12 p.

Magat, S.S. 2005. Crop Nutrition and Fertilization Management of Selected Tropical Fruit Crops. Los Banos, Laguna: PCARRD, Dept. of Science and Technology. 228 p.

Magat, S. S., Habana, J. A., Labarcon, A.G. and Froilan, L.B. 1981. Mineral nutrition (leaf) survey of coconut in the Philippines. I. Nutritional deficiency and fertilization. PCA-ARB, Diliman, Quezon City.

Magat, S.S. and Goh, K. M. 1988. Effects of chloride fertilizers on yield and uptake of chloride, potassium and sodium by fodder beet (Beta vulgaris L.) in two New Zealand soils. J. Agric. Sci., Camb. 111:207-216.

Magat, S.S. 1996. Notes on Mineral Nutrition of Coconuts:role of Nutrients, Its Deficiency Symptoms and Nutrient Needs. Technology Notes produced by CANFARMS, Agric. R \& D Branch. PCADiliman, Quezon City.

Magat, S.S. 1997. Coconut yield improvement in farmers' fields through research-based fertilization management in the Philippines. CORD J. 8(2): 1-25.

Margate, R. and S. S. Magat.1991. Research guide on the conduct of Agronomic and Nutrition Studies in Coconut. Book Series No. 119/1991. Published by PCARRDDOST and Rainfed Resources Development Project. Govt. of Phil. \& United States Agency for international Development.

Raquepo, M.C.M. and Pabustan, C.D. 2003.A Summary of Analytical Methods for Plant, Soil, Fertilizer and Water: A Quick Reference. Diliman, Quezon City: Plant and Soils Analysis Division, Research, Development and Extension Branch, Philippine Coconut Authority. 18p.

Secretaria, M.I. and J.N. Maravilla. 1997. Response of hybrid coconut palms to application of manures and fertilizers from field to full bearing stage. Plantations, recherché, developpement Journal. 4 (2):126-135. 
Cord 2009, 25 (2) 
Annex Table 1. Rainfall distribution of PCA-Davao Research Center 1993-2007

\begin{tabular}{|c|c|c|c|c|c|c|c|c|c|c|c|c|c|c|c|c|}
\hline \multirow{2}{*}{ MONTHS } & \multicolumn{2}{|c|}{1993} & \multicolumn{2}{|c|}{1994} & \multicolumn{2}{|c|}{1995} & \multicolumn{2}{|c|}{1996} & \multicolumn{2}{|c|}{1997} & \multicolumn{2}{|c|}{1998} & \multicolumn{2}{|c|}{1999} & \multicolumn{2}{|c|}{2000} \\
\hline & $\mathbf{R}$ & D & $\mathbf{R}$ & D & $\mathbf{R}$ & D & $\mathbf{R}$ & D & $\mathbf{R}$ & D & $\mathbf{R}$ & D & $\mathbf{R}$ & D & $\mathbf{R}$ & D \\
\hline JANUARY & 106 & 10 & 57 & 6 & 143 & 10 & 214 & 19 & 557 & 17 & 22 & 6 & 257 & 25 & 263 & 20 \\
\hline FEBRUARY & 48 & 6 & 41 & 6 & 118 & 7 & 104 & 15 & 98 & 14 & 44 & 9 & 120 & 11 & 392 & 23 \\
\hline MARCH & 221 & 7 & 102 & 11 & 118 & 5 & 130 & 15 & 73 & 9 & 9 & 2 & 246 & 24 & 255 & 25 \\
\hline APRIL & 111 & 7 & 241 & 9 & 65 & 5 & 324 & 18 & 302 & 13 & 38 & 4 & 357 & 28 & 528 & 26 \\
\hline MAY & 266 & 13 & 471 & 18 & 207 & 12 & 289 & 16 & 348 & 24 & 188 & 19 & 275 & 24 & 393 & 27 \\
\hline JUNE & 153 & 11 & 384 & 16 & 524 & 24 & 191 & 23 & 245 & 15 & 296 & 18 & 178 & 19 & 355 & 24 \\
\hline JULY & 586 & 12 & 94 & 6 & 152 & 16 & 418 & 17 & 229 & 16 & 440 & 24 & 351 & 21 & 172 & 24 \\
\hline AUGUST & 602 & 19 & 167 & 9 & 236 & 17 & 318 & 24 & 67 & 18 & 255 & 20 & 382 & 26 & 416 & 22 \\
\hline SEPTEMBER & 571 & 20 & 44 & 9 & 172 & 17 & 284 & 17 & 251 & 15 & 261 & 18 & 205 & 23 & 224 & 18 \\
\hline OCTOBER & 62 & 9 & 231 & 8 & 326 & 18 & 311 & 19 & 331 & 25 & 205 & 21 & 194 & 19 & 266 & 19 \\
\hline NOVEMBER & 144 & 11 & 153 & 9 & 140 & 15 & 201 & 17 & 153 & 14 & 220 & 25 & 216 & 26 & 161 & 12 \\
\hline DECEMBER & 264 & 15 & 74 & 6 & 152 & 19 & 86 & 11 & 54 & 12 & 224 & 16 & 317 & 24 & 193 & 11 \\
\hline TOTAL & 3,133 & 140 & 2,059 & 113 & 2,354 & 165 & 2,869 & 211 & 2,709 & 192 & 2,201 & 182 & 3,097 & 270 & 3,168 & 251 \\
\hline MEAN & 261 & 12 & 172 & 9 & 196 & 14 & 239 & 18 & 226 & 16 & 183 & 15 & 258 & 23 & 302 & 21 \\
\hline
\end{tabular}

\begin{tabular}{|c|c|c|c|c|c|c|c|c|c|c|c|c|c|c|}
\hline \multirow{2}{*}{ MONTHS } & \multicolumn{2}{|c|}{2001} & \multicolumn{2}{|c|}{2002} & \multicolumn{2}{|c|}{2003} & \multicolumn{2}{|c|}{2004} & \multicolumn{2}{|c|}{2005} & \multicolumn{2}{|c|}{2006} & \multicolumn{2}{|c|}{2007} \\
\hline & $\mathbf{R}$ & D & $\mathbf{R}$ & D & $\mathbf{R}$ & D & $\mathbf{R}$ & D & $\mathbf{R}$ & D & $\mathbf{R}$ & D & $\mathbf{R}$ & D \\
\hline JANUARY & 131 & 12 & 160.3 & 9 & 70.1 & 12 & 117.3 & 10 & 104 & 11 & 144.2 & 17 & 162.9 & 17 \\
\hline FEBRUARY & 97 & 8 & 176.4 & 12 & 117.4 & 9 & 126.3 & 11 & 38.6 & 5 & 125.3 & 17 & 124.4 & 14 \\
\hline MARCH & 249 & 17 & 59.8 & 9 & 123.4 & 18 & 110.6 & 8 & 70.5 & 8 & 280.9 & 14 & 79.2 & 9 \\
\hline APRIL & 126 & 12 & 168.9 & 10 & 252.4 & 11 & 230.7 & 18 & 192.1 & 10 & 98.9 & 12 & 78.4 & 11 \\
\hline MAY & 211 & 14 & 376.1 & 18 & 544.1 & 17 & 409.7 & 20 & 216.5 & 19 & 248.8 & 20 & 282.0 & 18 \\
\hline JUNE & 199 & 12 & 247.5 & 19 & 243.2 & 16 & 112.7 & 12 & 268.9 & 23 & 293.6 & 21 & 438.4 & 25 \\
\hline JULY & 373 & 19 & 152.0 & 12 & 361.4 & 23 & 431.4 & 23 & 187.2 & 17 & 254.3 & 12 & 251.9 & 21 \\
\hline AUGUST & 243 & 13 & 96.2 & 11 & 405.2 & 18 & 109.2 & 13 & 369.0 & 20 & 428.1 & 18 & 392.7 & 19 \\
\hline SEPTEMBER & 277 & 16 & 310.7 & 16 & 113.4 & 14 & 312.6 & 23 & 201.9 & 20 & 249.2 & 17 & 172.7 & 18 \\
\hline OCTOBER & 325 & 17 & 300.6 & 17 & 267.4 & 19 & 214.5 & 16 & 220.2 & 17 & 288.5 & 14 & 306.9 & 17 \\
\hline NOVEMBER & 425 & 11 & 303.2 & 17 & 233.0 & 15 & 124.9 & 10 & 139.6 & 16 & 201.3 & 13 & 166.6 & 15 \\
\hline DECEMBER & 140 & 6 & 78.4 & 7 & 274.1 & 17 & 230.6 & 19 & 305.5 & 25 & 106.3 & 13 & 154 & 19 \\
\hline TOTAL & 2,796 & 157 & 2,430 & 157 & 3,005 & 189 & 2,531 & 183 & 2,314 & 191 & 2,719 & 188 & 2,611 & 203 \\
\hline MEAN & 233 & 13 & 203 & 13 & 230 & 16 & 211 & 15 & 193 & 16 & 227 & 16 & 218 & 17 \\
\hline
\end{tabular}


Annex Table 2. Cost and return analysis of coconut + lanzones cropping system, @ Price level 1 ${ }^{\text {a }}$, PCA-DRC, cropping 1993 - 2007

\begin{tabular}{|c|c|c|c|c|c|c|c|c|c|c|c|c|c|c|c|c|}
\hline$F C: t(1+0)$ & a & 1993 & 1904 & 1995 & 1996 & 1997 & 1993 & 1999 & 3000 & 3001 & 3002 & 2003 & 3004 & 2005 & 2006 & 3007 \\
\hline \multirow{4}{*}{$\begin{array}{l}\text { Grows } \\
\text { Returas }\end{array}$} & & & & & & & & & & & & & & & & \\
\hline & Cocomut & 7.700 .00 & $27, \infty 00 \infty$ & 24,820000 & 31,620000 & $98,116.62$ & $97,705.85$ & $95,005.31$ & 47,89662 & $21,012.00$ & $47,601.00$ & $49,400,00$ & $65,756,00$ & $57,155,00$ & $48,128,00$ & $88,158.00$ \\
\hline & Lanzones & 0.00 & 0.00 & 0.00 & $0 . \infty$ & 0.00 & 0.00 & 0.00 & 0.00 & $4,200.00$ & $19,385 \circ 0$ & $16,4 \infty 0, \infty$ & 000 & $100,370.00$ & 7.55000 & $190,090,00$ \\
\hline & TOTAL & 7.70000 & 27.000 .00 & 2.830 .00 & 31.65000 & 35.116 .68 & 37.05 .85 & 35.005 .31 & 47.906 .62 & 25.23200 & 66.056 .00 & 59.53000 & 65.756 .00 & 157.525 .00 & 55.678 .00 & 238.235 .00 \\
\hline \multirow{4}{*}{$\begin{array}{l}\text { Pridacties } \\
\text { Cest }\end{array}$} & & & & & & & & & & & & & & & & \\
\hline & Cocontut & $10,864,66515$ & $12,3 \times 6 \quad 17000$ & $15,281.76586$ & $12,292.20019$ & $12,137.65663$ & 11,90098595 & $11,224.85028$ & 36,121 . Co18s & $15,282 \times 0046$ & $15,9 \mathrm{M}$ 7iles & $15, m .64758$ & $19,667.71400$ & 19,94691600 & 19,71255000 & 20,9075000 \\
\hline & Lanzones & 7695005586 & 960 egssts & 1,379190209 & 1,03206006 & 1.209218090 & 1,652 n376e & 582.957600 & $6 \pi .481127$ & $1,712.550194$ & 1.74. $9 \mathrm{mse}$ & 1,7749999 & $4,005,8958$ & $4,805 \mathrm{pesa}$ & 5,039864 & 5009364 \\
\hline & TOTAL & $11,044.17$ & $13,337.07$ & $17,259.96$ & $13,715,41$ & $13,346.98$ & $13,003.65$ & $11,757.79$ & $16,791.56$ & $16,945.25$ & $17,716,70$ & $17,552.64$ & $24,473.61$ & $24,752.81$ & 24,75189 & $36,010.12$ \\
\hline \multirow{5}{*}{$\begin{array}{l}\text { Net } \\
\text { Reparns }\end{array}$} & & & & & & & & & & & & & & & & \\
\hline & & & & & & & & & & & & & & & & \\
\hline & Cocomst & $-3,164.67$ & $14,629.89$ & $8,938.29$ & $19,327.79$ & $25,978.96$ & $25,754.92$ & $23,780,47$ & $31,775.59$ & $5,779.30$ & 91,62628 & $27,622.35$ & $46,088.29$ & $37,208.08$ & $28,415,47$ & $67,187.25$ \\
\hline & Lanzones & -769.90 & -50.90 & $-1,378.19$ & $-1, \infty 23.21$ & $-1,200,22$ & $-1,6527$ & -592.96 & -62048 & $2,507.45$ & $17,649,02$ & $14,645,01$ & $-4,805.90$ & $98,564.10$ & $2,510.64$ & $145,040,64$ \\
\hline & TOTAL & $-3,934.17$ & $13,662.93$ & $7,360.04$ & $17,904.58$ & $24,769.74$ & $24,102.20$ & $23,247,51$ & $31,105.05$ & 8.286 .75 & $49,269,30$ & $42,267.36$ & $41,282,39$ & $132,772.13$ & $30,926,11$ & $212,227.89$ \\
\hline
\end{tabular}

NPV @18 115,645.63

Sum of discounted gross benefits $=192,590.08$

Sum of discounted gross cost $\quad=76,944.45$

BCR $(18 \%)$

2.50

IRR (18\%)

$327.58 \%$

${ }^{\mathrm{a}}$ copra price $=\mathrm{PhP} 5.5 / \mathrm{kg}-\mathrm{Php} 21$ (farm gate)

lanzones fruit price $=\mathrm{PhP} 10 / \mathrm{kg}$ (farm gate) 